\title{
THE JUDICIAL OFFICERS OF THE TRANSVAAL HIGH COURT, 1877-1881
}

\section{Liezl Wildenboer*}

\section{ABSTRACT}

The Transvaal High Court was established in 1877. This was during the British annexation of the Transvaal (or Zuid-Afrikaansche Republiek), which ended in 1881 with the signing of the Pretoria and (and later) London Conventions. The first judge of this court, John Gilbert Kotzé, reported some of the judgements of this court for the period from 1877 to 1881 , where he also mentions the names of the persons appointed as judicial officers of the court. This contribution takes a closer look at the official opening of the court and at the various persons who served the court during this period either as members of the bench, or in the capacity of Attorney General or of Registrar and Master.

Keywords: Zuid-Afrikaansche Republiek; Transvaal High Court; judicial officers; John Gilbert Kotzé; Jacobus Petrus de Wet; Lewis Peter Ford; Eduard Johan Pieter Jorissen; Christian George Maasdorp; William Boase Morcom; Hendrik Willem van Breda; Henry Rider Haggard; Richard Kelsey Loveday; Pretoria Bar; Attorney General; Registrar and Master of the Transvaal High Court

* Senior lecturer, Department of Jurisprudence, College of Law, University of South Africa. 


\section{Introduction}

The first High Court of the Transvaal was established in $1877,{ }^{1}$ shortly after the first British annexation of the Zuid-Afrikaansche Republiek (for purposes of this contribution, "the Transvaal") ${ }^{2}$ that took place on 12 April of that year. ${ }^{3}$ It was eventually replaced with the "Hoog Geregtshof, Z.A. Republiek" (the High Court) after the Republic regained its independence on 8 August 1881 as a result of the signing of the Pretoria Convention, ${ }^{5}$ which ended the First Anglo-Boer War (1880 1881). ${ }^{6}$ The first session of the High Court took place in May 1877. ${ }^{7}$ Judge John Gilbert Kotzé, ${ }^{8}$ who was appointed by Sir Theophilus Shepstone ${ }^{9}$ as the first judge of

1 In terms of art 1 of the Proc of 18 May 1877, published in Jeppe \& Kotzé 1887: 703-707. Shepstone issued it in his capacity as Administrator, but the measure itself was drafted by Justice Kotzé: see Kotzé 1934: 422-427. On the Transvaal judicial system before 1877, see Hahlo \& Kahn 1960: 228-233; Van der Westhuizen \& Van der Merwe 1977a: passim.

2 This territory was also known as the South African Republic. See Wildenboer 2011: 339-340 n 2 for more details on the various names of this territory. Usually, I prefer to use the term "ZuidAfrikaansche Republiek" or its abbreviated form "ZAR" to avoid confusion with the later province of the Transvaal and the Republic of South Africa after 1961. However, for purposes of this contribution, when referring to the territory or to the High Court of this territory, the term "Transvaal" will be used, since this was the name used during the annexation, even though the Boers reverted to the old name, the Zuid-Afrikaansche Republiek, after the signing of the Pretoria Convention.

3 Earlier that year, President Burgers had announced the intended establishment of the High Court as part of the reform of the judiciary. See Kew 1979: 27-28. However, before these plans could be implemented, Sir Theophilius Shepstone annexed the ZAR on 12 Apr 1877 on behalf of the British government. See Proc of 12 Apr 1877, published in Eybers 1918: 448-453 doc 198. See, also, Schulze 2010: 106-107; Van der Merwe 2017b: 153-158.

4 See Proc of 9 Aug 1881 in Staats-Courant der ZA Republiek of 8 Aug 1881. Both the 1877 (see $n$ 1 supra) and the 1881 proclamations used the title "Hoog Geregtshof", which may be translated as "Supreme Court" or "High Court". However, since Kotzé recorded its judgements as those of the High Court, this latter term will be used throughout this contribution.

5 For a copy of the Pretoria Convention, see British Parliamentary Papers 1971: 511-518, C 2998; Eybers 1918: 455-463 doc 200. In terms of the Pretoria Convention, "self-government [was] restored to the inhabitants of the Transvaal Territory, subject to the suzerainty of [Britain]". The Convention was ratified by the Transvaal Volksraad on 25 Oct 1881, but was later replaced by the London Convention, dated $27 \mathrm{Feb}$ 1884, which restored independence to the Transvaal. For a copy of the London Convention, see Eybers 1918: 469-474 doc 204. For more on the First Anglo- Boer War in general, see Grobler 2018: passim.

6 The English call it the Boer (or South African) War, while the Boers call it the English War or the First Freedom War. Seeing that both parties participated, "First Anglo-Boer War" is preferable. The Second Anglo-Boer War took place from 1899 to 1902.

7 See part 2 infra.

8 See part 311 infra.

9 For more on Theophilus Shepstone, see Gordon \& Kotzé 1968: 746-753. Shepstone (1817-1893) was born near Briston, England. He came to South Africa at an early age with his parents as part of the group known as the 1820 British settlers. His father's missionary work with Reverend William Shaw enabled Shepstone to become fluent in both Xhosa and Zulu. This is one of the reasons why he was later appointed as the Natal Administrator of Bantu Affairs. He was knighted twice, in 1871 and in 1876 . He retired in 1880 and died in Pietermaritzburg. 
the court, reported its judgements delivered between July 1877 and June 1881 in a volume entitled Cases Decided in the High Court of Transvaal Province, with Table of Cases and Alphabetical Index (Kotzé's Reports). ${ }^{10}$

Much has been written on the High Court of the Transvaal, its jurisdiction and powers, ${ }^{11}$ and on the tension between the judiciary and the executive that eventually resulted in the constitutional crisis of $1897 .{ }^{12}$ The purpose of this piece is not to reconsider these matters. Instead, this contribution briefly investigates the opening of the first High Court of the Transvaal and provides some insight into the lives of those members of the bench and other judicial officers who served in the court during this period. The intent here is not to compile a detailed biography of each of these judicial officers, but rather to provide an overview of the various personalities who were actively involved in the day-to-day activities of the court during the first four years of its existence.

\section{The opening of the court}

The first session of the High Court took place on Wednesday, 23 May $1877 .{ }^{13} \mathrm{~A}$ full account of the event was published at the time in a local newspaper, De Volksstem, ${ }^{14}$

10 Kotzé 1885: passim; Van Niekerk 2013: 134-135. See, also, n 57 infra.

11 See Proc of 18 May 1877, published in Jeppe \& Kotzé 1887: 703-707. See, also, Van der Westhuizen \& Van der Merwe 1977b: 240-243.

12 For a recent analysis of the constitutional crisis and the events leading up to it, see Van der Merwe 2017a; Van der Merwe 2017b; Van der Merwe 2018a; and Van der Merwe 2018b.

13 Kotzé 1934: 430 (and, following him, Roberts 1942: 367 and Van der Westhuizen \& Van der Merwe 1977b: 241) incorrectly gives the date as 22 May. He may be forgiven this oversight since he wrote his memoirs only sixty years later. For a copy of the first page of the minutes of these proceedings in Kotzé's own handwriting, see Roberts 1955: 176.

14 See British Parliamentary Papers 1971: 488-489, C 2891, Despatch of Lanyon to Earl of Kimberley, 1 Feb 1881 at 488-489 for a description of the circulation of De Volksstem in 1881. Lanyon estimated that only around 1000 copies of the newspaper were printed each week, and that only 3.5 per cent of the Dutch-speaking inhabitants read the paper each week. This he put down to various factors, including his suspicion that nearly half of the printed copies were sent to the outlying towns and to towns outside the borders of the Transvaal; to the non-existence of reading rooms; and to the logistical problems in distribution the newspaper due to the distances between farms. Despite this supposedly low number of readers, Lanyon still found "a series of seditious articles, culminating in a rebellious exhortation" published in the newspaper to have "contributed largely to bring about discontent and to sow the seeds of the rebellion that followed". Theal 1919 vol 2: 114-115 provides more details on one of these "seditious articles". He recounts that the editor, Celliers, was arrested after reporting that 110 inhabitants of Wakkerstroom had announced that they would not have any dealings with the British, nor pay their taxes. Celliers was tried for sedition in the Magistrate's Court in Pretoria. He was found guilty and sentenced to one month in prison, as well as to a fine of $£ 25$. However, Theal does not view this as the principal event that resulted in the war that followed. Rather, he blames the incident of Bezuidenhout's wagon, where a group of 300 burgers under Commandant Piet Cronjé forcefully removed the wagon on the morning that it was due for sale in execution to pay Bezuidenhout's outstanding taxes to the British government. Word of this incident spread fast and the number of protesters soon grew to 1500 . The matter culminated in a standoff between Kruger and the colonial secretary, 
and is worth recounting here. ${ }^{15}$ The proceedings commenced at $10 \mathrm{~h} 00$ at the Volksraad Hall, ${ }^{16}$ there not being an official court building at the time. ${ }^{17}$ Kotzé remembered ${ }^{18}$

George Hudson. For more on Celliers and the history of De Volksstem, see Nienaber 1972: 128 129; Behrens 1955: 335-342. Johannes François Celliers (1839-1895) was born in Paardenberg, Malmesbury. He received his basic education in the Paarl and became a journalist at Het Volksblad in Cape Town at the age of twenty-four. In 1872, President Burgers invited Celliers to establish a newspaper in Pretoria. Celliers arrived in Pretoria in Apr 1873, where he soon acquired the contract for the printing of the Staats Courant and other state publications from J Cooper Rouse. He established his own newspaper, De Volksstem, the first issue of which was published on 8 Aug 1873. Celliers was a fierce supporter of President Burgers, and De Volksstem was a progovernmental publication. Due to his trial and the war, De Volksstem was not published between 20 Dec 1880 and Apr 1881. After the war, Celliers continued with De Volksstem, but also became increasingly involved in politics, and finally sold the newspaper to the government in 1888 for $£ 20$ 000. He was married to Magdalena Bisseux and six children were born of the marriage. The eldest son was the well-known Afrikaans poet, Jan FE Celliers, and the second daughter, Susanna Wilhelmina Celliers, would later become the first wife of the well-known sculptor, Anton van Wouw.

15 See 30 May 1877 De Volksstem. All quotes in this part are taken verbatim from thenewspaper.

16 Presumably, this is the so-called Goewermentsgebou (also known as the Volksraad building or government building, not to be confused with Government House, also referred to as the Presidency), which was built in 1865 (see Engelbrecht 1955: 15) and of which an image appears in Meiring 1955: 151 and Grobler 2018: 15. In the style of the time, the first Goewermentsgebou consisted of a simple rectangular, single-storey construction with a thatched roof and an open stoep or patio. It was situated on the south-western corner of Church Square, where the Raadsaal was erected in 1889: see Grobler 2018: 15. For a description of this and other structures, see Meiring 1955: 158-161. On the early architectural style of the Transvaal before the 1890s in general, and the philosophy behind the town planning at the time, see Holm 1998: 56-64. The early lay-out and architecture of Pretoria was based on that of Graaff-Reinet, from where many of the Voortrekker families had come (Holm 1998: 63; see, also, Meiring 1955: 157).

17 The Court would eventually be housed in a building known as the High Court of Justice, situated at the corner of Bureau Lane and Andries (today, Thabo Sehume) Street; a sketch of it appears in Roberts 1955: 188. In 1897, the building of the Palace of Justice, situated on the corner of the current Palace and Madiba streets, commenced. The architect was Sytze Wierda, who hailed from the Netherlands. The foundation stone was laid by Paul Kruger himself on 8 Jun 1897, under which was placed "a copy of the Constitution of the ZAR, a copy of each of the newspapers then in circulation in the Republic, a copy of the 'Government Gazette', a complete set of the coins of the Republic and a copy of the plans of the building": see Picton-Seymour 1977: 277-278. The Palace of Justice was completed in 1899, although the interior was only completed after the Second Anglo-Boer War, during which the building was used as a hospital. See Meiring 1955: 162-163. For the floor plan and a sketch of the frontal view of the Palace of Justice, see Holm 1998: 76. For a more detailed description of the interior and exterior of the Palace of Justice, see Picton-Seymour 1977: 278-279.

18 This article draws extensively on the first of the two volumes of his memoirs, published almost sixty years later (Kotzé 1934). Apart from making entertaining reading, it is perhaps also good to know that these two volumes indeed reflect events and facts with sufficient accuracy. See Bergh 2013: 107 and 120, who, after analysing some of the judge's reminiscences regarding Paul Kruger and finding that Kotzé may have been influenced in his views on Kruger due to personal biases, nevertheless concludes that the volumes provide "the researcher with valuable historical information" due to the fact that Kotzé "was meticulous in writing down his observations" and that he consulted other independent sources at the time of writing to confirm his memories. 
that there was "neither pomp nor music on this occasion, for Themis delighteth not therein, but in truth in judgment". ${ }^{19}$ The newspaper observed:

Of course, there was not much of a Bench yet, the Bench being a chair placed behind the desk of the Chairman of [the] Volksraad. In front of this desk a table was placed for the attorneys, of whom thirteen were present, including the Acting Attorney General. ${ }^{20}$ The attendance of the public was not large. At the appointed hour His Excellency the Administrator ${ }^{21}$ and Aidede-camp, Col. Brooke, entered the hall, followed by Mr. Justice Kotzé, who took his seat on what we shall by courtesy call the Bench.

Also present were HW van Breda ${ }^{22}$ in his capacity as the newly appointed Master and Registrar of the High Court, and CJ Juta ${ }^{23}$ in his capacity as the newly appointed Sheriff of the High Court. ${ }^{24}$ Van Breda read out the Proclamation of 18 May 1877 regarding the constitution of the Court, and then Justice Kotzé administered the oath to both Van Breda and Juta.

19 Kotzé 1934: 430.

20 LP Ford. See part 321 infra.

21 Sir Theophilus Shepstone. See n 9 supra.

22 See part 331 infra.

23 I could not find much on Coenraad Jacobus Juta. He was the younger brother of the better-known Cape Town bookseller and founder of the publishing company bearing the family name, Jan Carel Juta (for more on whom, see Arkin 1972: 352-353). Coenraad was born on 3 Apr 1827 in Zaltbommel, Gelderland, in the Netherlands. He married Renette (Reinetta) Johanna Margaretha Biccard on 12 Nov 1857 in Cape Town; ten children were born of this marriage. See $s v$ "Coenraad Jacobus Juta" Geni (6 Jun 2019) available at https://www.geni.com/people/Coenraad-JacobusJuta-SV-PROG/6000000021986566362 (accessed 8 Nov 2019); and sv "Coenraad Jacobus Juta" Wikitree (17 Jul 2019) available at https://www.wikitree.com/wiki/Juta-4 (accessed 8 Nov 2019). He accepted the position of Secretary of State of the ZAR a week before the annexation, on 5 Apr 1877: see National Archives Repository (Public Records of Former Transvaal Province and its predecessors as well as of magistrates and local authorities (hereafter "TAB")) SS 233 R1206B/77; and took his oath two days later: see TAB SS 233 R1207B/77 (dated 7 Apr 1877). The first official letter written in his new capacity as Sheriff of the High Court is dated 28 May 1877, and concerned his request for more information regarding his new position, namely on the duties of his office, on messengers of the courts and on fees: see TAB SS 237 R1996/77. A year after his appointment as Sheriff, he requested a raise: see TAB SS 278 R1343/78 (dated 1 May 1878). He repeated this request a year later: see TAB SS 341 R1533/79 (dated 29 May 1879). In Mar 1883 he appointed his son and namesake as clerk to his office: see TAB SS 800 R1334/83 (dated 29 Mar 1883). He acted as Registrar of the High Court on occasion: see TAB SS 843 R4051/83 (dated 29 Aug 1883) and TAB SS 1197 R1527/86 (dated 3 Apr 1886). In 1884, two locals named Simpson and Schappert sent a testimony that Coenraad had performed his duties well: see TAB SS 895 R485/84 (dated 29 Jan 1884). Other documentation sent in his official capacity concerned a request for permission to order a register for civil cases: see TAB SS 944 R2526/84 (dated 28 May 1884); and a request for office furniture: see TAB SS 986 R4536/84 (dated 26 Sep 1884). In 1887 and probably due to old age (Coenraad was almost sixty), he requested that his son stand in for him as acting Registrar in the criminal circuit court: see TAB SS 0 R1986/87 (dated 29 Mar 1887). He died in Pretoria two years later, on 8 Sep 1889.

24 Article 8 of the Proc of 18 May 1877 provided for the establishment of the office of the Master and Registrar, as well as for the office of the Sheriff (also known as the High Sheriff or the Hoofdbaljuw). 
After this, the acting Attorney General, LP Ford, petitioned the Court on behalf of himself and each of the other attorneys present, to be admitted as advocates and/ or attorneys. ${ }^{25}$ All the lawyers present were then admitted and duly sworn in by the court in accordance with their petitions, either as advocates and attorneys (that is, as members of the Bar), ${ }^{26}$ or as attorneys only (that is, as members of the Side- Bar). ${ }^{27}$ At this point, Justice Kotzé felt it necessary to observe that "no reflection was cast upon those who had been admitted as Attorneys only" and that they had been recommended as such by the Board of Examination at its meeting the previous week..$^{28}$

25 Previously, the Transvaal had allowed for a dual-capacity legal system, meaning that attorneys could practise as advocates and vice versa. However, this changed after the annexation. In terms of art 9 of the Proc of 18 May 1877, a divided legal profession was established. Nevertheless, there were certain exceptions: first, those lawyers who had practised in both branches before this proclamation could apply for admission as both (art 10 of the Proc); secondly, members of the Bar and Side-Bar were permitted to move between the two branches subject to a six-month quarantine. See Wildenboer 2010: 219-220; Wildenboer 2011: 349-350.

26 The ten individuals sworn in as advocates and attorneys were Ford (see part 321 infra

- here admitted as advocate, attorney, notary public, conveyancer and sworn translator); Stephanus Jacobus Meintjes (admitted as advocate, attorney, notary public, conveyancer and sworn translator); Abraham Isac Munnich (admitted as advocate, attorney, notary public and conveyancer); Julius Franck (admitted as advocate, attorney and notary public); Johannes van Eck (admitted as advocate, attorney and notary public); Johan Carel Preller (admitted as advocate, attorney, notary public, conveyancer and sworn translator); Henry William Alexander Cooper (admitted as advocate and attorney); Mauritz de Vries (admitted as advocate, attorney, notary public and conveyancer); Paulus Nijhoff (admitted as advocate, attorney and notary public); and Pierre Jean Louis Eckhout (admitted as advocate and attorney). See 30 May 1877 De Volksstem; Roberts 1995: 176-179.

27 The three individuals sworn in as attorneys only were Francis Frederick (Frank) Zeiler (also admitted as conveyancer); Adam Francis Schattenkerk; and Hendrik Willem van Rossem. See Roberts 1955: 179.

28 The Board of Examinations had also undergone a complete change of membership. Before the annexation, the previous members had been the State Attorney (EJP Jorissen), I Munnich and JC Preller. (Preller had resigned; Munnich was not available; and Jorissen had left the country in May 1877 for London as part of the two-man deputation - the other member being SJP Kruger - to petition the British government regarding the independence of the Transvaal: see Kruger 1975: 7693; Leyds 1906: 271-272. They had five interviews with the British Minister of Colonies, Lord Carnarvon, but could not persuade him to host a referendum for or against the annexation, or that they represented the majority of the Transvaal inhabitants: see Grobler 2018: 12-13.) As their successors, the British government appointed Justice Kotzé as chairman of the Board, as well as SJ Meintjes and $\mathrm{M}$ de Vries. Their first meeting had taken place a week earlier, on Thursday, 17 May 1877: see 16 May 1877 De Volksstem. A year later, a new Board of Examiners in Law and Jurisprudence was established, and would constitute four members, namely the judge of the High Court, the Attorney General and two advocates to be nominated by the government: see GN 76 Transvaal GG of 4 Jun 1878, which also set out the rules for the examination, as well as the subjects that candidates would be examined on. The two advocates then appointed as members of the Board, namely SJ Meintjes and HWA Cooper, were announced two weeks later: see GN 79 Transvaal GG of 18 Jun 1878. For more on the Transvaal Board of Examiners, see Wildenboer 2011: 350-354. 
Ford then read a short address on behalf of the Bar and Side-Bar, welcoming the new judge, and pledging their willingness to support him in order to "forward the ends of justice in this country". ${ }^{29}$ Kotzé responded with his own address, expressing gratitude for the welcome and remarking that the establishment of the new High Court was in accordance with the wishes of the community. ${ }^{30} \mathrm{He}$ then impressed upon those present the great responsibility resting on their shoulders:

The administration of Justice in this territory has, to a great extent, hitherto existed but in name. The old courts now abolished, were wholly unsuited to the growing wants and circumstances of the community; and in many instances, as I have been informed on good authority, there has been a gross miscarriage of justice. ... You occupy a very honourable position, and I have no doubt you will practice your calling with that integrity and ability, which are its due. An able bar is quite as necessary for the proper administration of justice as a well constituted bench is - the one without the other would practically be useless.

The court then proceeded with hearing its first motion, an ex parte application for restraining the respondent from removing wood from the farm, Louwsbaken, which was mortgaged to the Cape Commercial Bank. ${ }^{31}$ Kotzé J granted an interim order until its next sitting on 5 July, and the court was adjourned.

29 The full address appeared verbatim in the newspaper: "May it please your Lordship.- We the undersigned, members of the Bar and Side Bar of your hon'ble Court, beg respectfully to welcome your Lordship on this momentous occasion of the opening of the first High Court, an event long looked forward to and desired not only by us, but also by the enlightened portions of the community. The appointment of your Lordship as our first Judge has given us unbounded and heartfelt satisfaction on account not only of your Lordship's birth and education, but also by reason of the golden opinion which your Lordship has already won in the Cape Colony. Although so short a time amongst us, we have already learnt to honour and respect you, and we sincerely trust that the good understanding which has arisen between us may continue. We pledge ourselves to support your Lordship in your endeavours to forward the ends of justice in this country, and hope that your Lordship will ever find us willing to submit to your wishes and desires in attaining that most desirable object. In conclusion we trust your Lordship may long be spared to us, and as you are about leaving for the Cape Colony for your wife and family, we wish you a pleasant and safe journey and a speedy return to our midst.- We have the honor [signed by the Bar and Side Bar]." See 30 May 1877 De Volksstem.

30 Similar to Ford's reference to the "enlightened portion of the community" in his address (see n 29 supra), Kotzé also qualified this as being "the intelligent portion of the community". This clearly implied that not everybody was in favour of the abolishment of the old courts or the establishment of the new High Court.

31 The case of Durham v Fleischmann is unreported. Advocate SJ Meintjes represented the applicant, who was the manager of the bank. 


\section{The first judicial officers of the Transvaal High Court}

\section{The bench}

\section{John Gilbert Kotzé32}

Kotzé was born in Cape Town on 5 November 1849. He was educated at the Tot Nut van het Algemeen Institute ${ }^{33}$ and later at the South African College from 1864 to 1868. He then left for England to matriculate and to read for law at the University of London. He was admitted to the Inner Temple in 1872 and called to the Bar on 30 April 1874. He soon after returned to South Africa and was admitted to the Cape Town Bar on 18 August 1874. In June 1876 he moved his practice to the Bar of the Eastern Districts Court in Grahamstown. Less than a year later he was offered the position of Chief Justice of the Transvaal by President Burgers ${ }^{34}$ and was appointed the first judge of the High Court of the Transvaal on 19 May 1877. However, there is a bit more to this appointment than first meets the eye..$^{35}$

As part of his judicial reform programme, President Burgers had originally proposed a three-judge bench for the High Court. He had offered the position of Chief Justice to Kotzé, who accepted the position. ${ }^{36}$ However, when Kotzé eventually arrived in Pretoria by train on 28 April $1877,{ }^{37}$ the Republic was no longer independent, and Burgers had been deposed..$^{38}$ Probably due to financial reasons, ${ }^{39}$ Shepstone decided to ignore Burgers' plans and instead opted for a single-judge bench. $\mathrm{He}$ offered Kotzé the position of ordinary judge, who accepted on the understanding

32 See, in general, Kotzé 1934: passim; Kotzé 1949: passim; Hiemstra 1968: 458-461; and Roberts 1942: 367-368. There is an image of him as a young man in Scott 1982: 100.

33 Anonymous 1903: 101.

34 Kotzé 1934: 207; Van der Merwe 2017b: 165-166.

35 His appointment has been discussed in detail by various scholars. In general, see Kew 1979: $27-$ 52; Schulze 2010: 106-111; and Van der Merwe 2017b: 166-167.

36 Burgers offered the other two justice positions to JC Preller and AI Munnich. Munnich accepted the position, but Preller declined. See Kew 1979: 32; Van der Merwe 2017b: 156 esp n 108.

37 Kew 1979: 34. His family eventually arrived in Pretoria only on Thursday, 19 Jul 1877. They had an accident on the way, when the wagon they had been travelling in capsized near Bamboesspruit. Mrs Kotzé sustained a few bruises to her face, and Kotzé himself received a cut on the head. The children and the nurse were luckily not injured. See 25 Jul 1877 De Volksstem; for Kotzé's own version of the event, see Kotzé 1934: 434.

38 Shepstone had sent a letter to Kotzé at Kimberley, hoping to forestall him there, but the letter missed Kotzé with a few hours. See Kew 1979: 34.

39 Idem at 34-48 mentions various other factors that also played a role in Shepstone's decision to offer the position to Kotzé. These factors included the uncertainty regarding the administrative consequences of the annexation of the Transvaal, the urgent need for the opening of the newly established High Court, the lack of other suitable and qualified candidates, as well as media pressure. Kotzé seemed to be the right man at the right time: he was by far the best qualified candidate available at short notice, and he was interested. 
that he would later be made Chief Justice when additional judges were appointed. ${ }^{40}$ Great was his dismay, therefore, when instead JP de Wet was named to be appointed as Chief Justice in May 1880. ${ }^{41}$ Despite protestations from Kotzé ${ }^{42}$ and members of the Bar, ${ }^{43}$ De Wet's appointment was confirmed and Kotzé had to be content with the more junior position of first puisne judge. Nevertheless, he was redeemed not long after, when, on 8 August 1881, the reinstated ZAR government appointed him as the Chief Justice of a three-judge bench. ${ }^{44}$

40 Kew 1979: 51 esp n 57; Schulze 2010: 107; Kotzé 1934: 417-420.

41 For a discussion of the reasons for the appointment of an outsider, see Kew 1979: 62-69. For a more detailed discussion of De Wet's appointment, as well as the response of Kotzé and the Bar, see Schulze 2010: 106-111, who speculates that De Wet's appointment and Kotzé's slighting was due to government and personal politics. See Schulze 2010: 117-118 for a discussion of De Wet's judicial experience at the time of his appointment, and of the political reasons behind the British government's choice to appoint him. Schulze points out that none of Kotzé's protestations regarding De Wet's appointment hinged on De Wet's lack of experience or ability as a suitable candidate. See, also, Van der Merwe 2017b: 170 171.

42 See Kotzé 1934: 702-712 for his own description of his response to De Wet's appointment, and 715-717 regarding the support he received from the Bar and the general public. However, what is less well known is that Kotzé and De Wet had met previously in Grahamstown, and that Kotzé, despite being eleven years younger than De Wet, had impressed the local court to such an extent on that occasion, that he had won the case in which they were involved. The (unreported) case was that of Court v Jubb; De Wet acted in his capacity as Solicitor General, and Kotzé represented the defendant. While De Wet saw the issue as a simple one, requiring no authorities to be cited, Kotzé that day brought with him to court a large number of books. Dwyer J then commented to Kotzé that surely he wasn't going to “quote from all those authorities on so simple a point?", to which Kotzé responded that he indeed was. The judge then sat back, put his hands in his pockets and stared at the ceiling until he became persuaded by Kotzé's "well arranged and eloquent argument", on which he eventually also complimented the young advocate. See Anonymous 1903: 102. The memory of this incident must have made it all the more difficult for Kotzé when De Wet was eventually appointed as Chief Justice, a position that Kotzé had believed was his.

43 The members of the Bar being JC Preller and SJ Meintjes. See Kotzé 1934: 715-716; Schulze 2010: 108-109.

44 See GN 3 Staats-Courant der ZA Republiek of 8 Aug 1881. The Government Notice is actually dated 8 Aug 1881, although it was only officially published the day after. The Proc, published in the same StaatsCourant, establishing the new post-independence High Court (Hoog Geregtshof, Z.A. Republiek) referred back to the original Volksraad decision (dated 7 Mar 1877) establishing the court before annexation. The 1881 court would therefore be a three-judge court, of which the two criminal law judges would be appointed later. Kotzé's appointment was but one of many governmental and judicial appointments officially announced in the same edition of the Staats-Courant: other judicial appointments included Henri van Rossem as Registrar and Master of the High Court and Cornelis Johannes Juta as the Chief Sheriff (Hoofdbaljuw) (GN 4); EJP Jorissen as Attorney General (Staatsprocureur) (GN 5); JPJ van Nickelen Kuijper as clerk to the Orphan Chamber (Klerk in het Kantoor van den Weesheer), as well as Johannes C Minnaar and ACH Lorentz as first and second clerks to the Deeds Office respectively (1ste Klerk en $2 e$ Klerk in het Registratie-kantoor) (GN 6); for the district of Pretoria, Johannes Zulch de Villiers as magistrate, J Vogel as prosecutor, Fredrick H Taynay as acting magistrate's clerk and Gerard C van Dam as acting messenger of the court (GN 7); for the district of Potchefstroom, Theunis Johannes Krogh as magistrate, Herman Pieter Kluever as first magistrate's clerk and prosecutor, Frans Botha as second magistrate's clerk and assistant postmaster, GC Alexander van Dam as messenger of the court, and Isaac van Alphen as postmaster (GN 8); and, for the district of Rustenburg, Casper G Bodenstein as magistrate and JC Brink as magistrate's clerk and prosecutor (GN 9). 
Much has been written about Kotzé. ${ }^{45} \mathrm{He}$ was a respected judge throughout his career, not only for his judicial activities on the bench, but also for his efforts at raising the quality of the bench and the Bar. He was critical of the Transvaal dualpractice system and was instrumental in its transformation into one divided into attorneys and advocates. ${ }^{46} \mathrm{He}$ further proposed changes to the composition of the Board of Examiners responsible for testing potential legal practitioners, and suggested changes to the contents of the material that candidates would be tested on. ${ }^{47}$ One other factor that also contributed to the efficacy of legal representation in court, was the new law library established in 1878. It consisted of Roman-Dutch and English law books bought with funds made available by the British government, and was augmented by additional books sponsored by Kotzé and members of the Pretoria Bar. ${ }^{48}$ Kotzé encouraged members of the legal profession to consult these works and even gave them access to his own private collection when necessary ${ }^{49} \mathrm{He}$ also drafted regulations for the use of the library, and made sure that the library was housed near the court room to facilitate regular and easy access by the legal practitioners. This proved to be successful as the quality and efficiency of arguments heard by the court soon improved. Kotzé remembered: ${ }^{50}$

The work of the Court was disposed of with reasonable dispatch. There was not much time wasted in needless examination and cross-examination of witnesses, which is rather a failing of the present day. There were, with perhaps one or two exceptions, no long-winded men at the local bar, for the Court had been careful from the first to impress upon the pleaders the necessity of paying due regard to the relevancy of evidence, and its effect upon the points in issue in the case. Hence several of the practitioners acquired an aptitude in handling witnesses, with the result that time and costs were saved. I still have pleasant recollections of my early experience on the bench during the period of annexation, and of the good service and loyalty of these old practitioners.

45 See, for example, Kew 1979: passim. See, also, Kotzé 1934: passim and Kotzé 1949: passim. During the siege of Pretoria (Dec 1880-Mar 1881), when the inhabitants were evacuated to military camps, Kotzé was appointed wardmaster, whose duties included the distribution of rations to the women and children in the camps, and seeing to their general health and comfort. See, Anonymous 1903: 103. There is a photo of Kotzé performing these tasks in Grobler 2018: 92. For more on the siege of Pretoria, see idem at 79-114.

46 Wildenboer 2011: 349-350 esp n 77. See, also, Kew 1979: 87-88.

47 See Wildenboer 2011: 351 n 87.

48 See Kotzé 1934: 540-541; Kew 1979: 85-86. The British government granted £300 for the acquisition of the law books in response to a request by EJP Jorissen during his trip to England as part of the first deputation to protest the annexation: see n 28 supra.

49 Kotzé 1934: 541.

50 Ibid. 
He remained on the bench until February 1898, when he was controversially dismissed by President Paul Kruger after the court's judgement in the infamous case of Brown v Leyds NO. ${ }^{51}$

Kotzé's law career continued subsequent to his dismissal. After a trip to London, he returned to Pretoria where he set up a legal practice. In August 1900, he was appointed as the Attorney General of Southern Rhodesia and in this capacity also became a member of its Executive Council. ${ }^{52}$ In 1902 he became King's Counsel. The following year, he was appointed judge of the Eastern Districts in Grahamstown, and in 1904 he became Chief Justice of the same division. He was appointed judge of the Cape Provincial Division in 1913, and was raised to Judge President in $1920 . \mathrm{He}$ became a member of the bench of the Appellate Division in 1922, where he served until his retirement in 1927.

Although Kotzé's legal training was based on English law, he contributed much to the development of Roman-Dutch law in South Africa. ${ }^{53}$ His English translation of Van Leeuwen's Het Rooms-Hollands Recht in the $1880 \mathrm{~s}^{54}$ made this source much more accessible to non-Dutch speaking lawyers. He was a member of the Grotius Society in London. ${ }^{55} \mathrm{He}$ also published two compilations of Transvaal

51 (1897) 4 Off Rep 17. The so-called constitutional crisis that developed as a result of this judgement involved Kruger's government protesting against the court's ability to declare legislation and Volksraad decisions invalid. This saga has been much written about and commented on by various scholars and lawyers. See, for example, the four-part article by Van der Merwe on the constitutional crisis of the ZAR (Van der Merwe 2017a; Van der Merwe 2017b; Van der Merwe 2018a; and Van der Merwe 2018b); and Bergh 2013: 115-116.

52 See, also, Anonymous 1900: 207.

53 At the opening of the Appellate Division's term on 16 Apr 1940, two weeks after Kotzé's death, the then Chief Justice, NJ de Wet, made the following comments regarding the start of Kotzé's career on the bench (as cited in Anonymous 1940: 160): "He was called at an early age to the Bench of the Transvaal Republic, and it is almost impossible for us to realise the difficulties under which he must have laboured. Modern text-books dealing with Roman-Dutch law were non-existent so that, to determine any legal question, a laborious reference to the old authorities was necessary. Added to this he was all alone, at any rate for several years, with nobody to consult and with only the nucleus of a Bar to give him assistance. Under those circumstances the easiest course would have been to seek guidance from the much more conveniently available text-books and reports of the English law. But that was not the way of Mr. Justice Kotzé. Not only did he hold the torch of Roman-Dutch law on high in his judgments, but he found time to give the legal world the benefit of his study and research in his excellent annotated edition of Van Leeuwen's Commentaries on the Roman-Dutch law. A career so auspiciously begun was continued with the same success till his retirement from the Bench, just fifty years after he had first taken a seat on it."

54 The translation was published in London in two volumes in 1882 and 1886. See Roberts 1942: 184.

55 The Grotius Society was a London-based organisation, established in 1915 during the First World War. Its purpose was to "afford facilities for discussion of the Laws of War and Peace, and for interchange of opinions regarding their operation, and to make suggestions for their reform, and generally to advance the study of international law". Although its membership was restricted to British citizens, the Society catered not only for views from a British perspective or for those that favoured British interests. See Ilner 1916: 381. The Society was dissolved in 1958, when it merged with the Society of Comparative Legislation to form the British Institute of International and Comparative Law. 
legislation ${ }^{56}$ and was involved in the compilation and review of several volumes of Transvaal case law, ${ }^{57}$ among others. ${ }^{58}$ In 1896 he was awarded the Knight Grand Cross of the Portuguese Order of the Conception by the King of Portugal. In addition, two honorary doctorate degrees were conferred on him, namely by the University of the Cape of Good Hope in 1912 and by the University of Cape Town in 1927. He has been praised by members of the legal fraternity for being an "honest and fearless Judge", ${ }^{59}$ for "his genuine interest in and his sympathy for his fellow human beings", for being "a man who was an example to all of us in his industry, sincerity and cheerfulness", ${ }^{60}$ and for "his unfailing courtesy to members of the Bar, and especially his kindness and courtesy to juniors". ${ }^{61} \mathrm{He}$ has been described as "an outstanding jurist with a thorough knowledge of Roman-Dutch law". ${ }^{62}$

Kotzé was married twice. His first marriage was to Mary Aurelia Bell, and seven children born of this marriage survived to adulthood. His second marriage was to Margaretha Jeldina Doornbos. He died in Cape Town on 1 April 1940.

\section{Jacobus Petrus de Wet}

As already mentioned, the only other member of the Transvaal bench during the period under consideration was Justice JP de Wet. A discussion of his law career recently featured in an excellent article by Heinrich Schulze. ${ }^{63}$ Accordingly, only a few facts need be mentioned here. De Wet was born in Cape Town on 25 August $1838 .{ }^{64}$ After first enrolling at the University of Leiden, he soon left for England and obtained his BA degree at the University of London. He was called to the Inner Temple as a barrister-at-law in June 1863; in December of the same year he was admitted to

56 The first, entitled De Locale Wetten der Zuid-Afrikaansche Republiek, 1849-1885, was published in 1887 with Fred Jeppe as co-editor. The second, entitled De Locale Wetten en Volksraadsbesluiten der Zuid-Afrikaansche Republiek, 1886-1887, was published in 1888.

57 Apart from Kotzé's Reports mentioned above (see n 10 supra), Kotzé was also involved in all four volumes of the Reports of Cases Decided in the Supreme Court of the South African Republic, published between 1881 and 1892. He was namely the reporter of the first and second volumes (with SH Barber for the latter volume) and, due to an increased work load by that time, for the review only of the third and fourth volumes (reported by SH Barber and WA Macfadyen). Kotzé also revised the first three volumes (published between 1894 and 1896) and translated the fourth volume (published in 1897), of the Official Reports of the High Court of the South African Republic. See Van Niekerk 2013: 134-138.

58 For a full list of his law publications, see Roberts 1942: 184. In addition, he published his memoirs in two volumes (Kotzé 1934: passim and Kotzé 1949: passim, the latter appearing post-humously), which provides fascinating insight into the events, personalities and politics of his time. See, also, n 18 supra.

59 Anonymous 1940: 159.

60 The latter two quotes both as per Van Zyl JP, cited in Anonymous 1940: 159.

61 As per De Wet JP, cited in Anonymous 1940: 160.

62 Scott 1982: 100.

63 Schulze 2010: passim.

64 Idem at 101. 
the Cape Bar. ${ }^{65}$ In 1864 he joined the Eastern Cape Bar at Grahamstown. ${ }^{66}$ In 1873 he was appointed Solicitor General of the Cape, and in 1878 Recorder of Griqualand West ${ }^{67}$ In May 1878, he was offered the position of Chief Justice of Transvaal, which he accepted ${ }^{68}$ Despite protestations to his appointment, his term was uneventful, probably due at least in part to Kotzé's admonishment to the members of the local Bar that "the public interest dictated that nothing but the most amicable relations should exist between Mr. De Wet and [himself], and that such would likewise be the proper course for the bar to pursue". ${ }^{69}$

After independence was restored to the Transvaal, De Wet was not offered a seat on the new three-judge bench. Fortunately for him, though, the British government then offered him the position of acting Chief Justice of Ceylon, a British colony that also applied Roman-Dutch law. ${ }^{70} \mathrm{He}$ accepted the offer and left for Ceylon, where he served from 1882 to 1883. Afterwards, he moved to England, where he was knighted at Windsor Castle on 19 July $1883 .{ }^{71} \mathrm{He}$ died in Eastbourne, England on 19 April $1900 . .^{72}$

\section{The Attorneys General ${ }^{73}$}

\section{Lewis Peter Ford $^{74}$}

Ford was born in London, England on 26 January 1846, and moved with his parents to Cape Town five years later. He received his legal training at the South African College and was admitted to practice at the Cape Bar on 4 December $1866 .{ }^{75}$ After

65 Idem at $102-103$

66 Idem at 103-104.

67 Idem at $104-105$.

68 Idem at $108 \mathrm{n} 51$. He delivered the judgement in thirteen of the cases reported in Kotzé's Reports (I have added the dates and certain information to each citation for ease of reference): Mchattie $v$ Twycross 1880 Kotzé 190 (Jun 1880); Welsh v Bernhard, Cohen \& Co 1880 Kotzé 192 (Jun 1880); Van Breda v Johnston; Colquhoun v Brits; Green v Gibaud 1880 Kotzé 193 (Jul 1880); Twycross v HcHattie 1880 Kotzé 198 (Jul 1880); Coventry Brothers v Kingsmill 1880 Kotzé 203 (Jul, Aug 1880); Ex parte Bok 1880 Kotzé 223 (Aug 1880); Conradie v Dunell, Ebden \& Co 1880 Kotzé 227 (Oct 1880); Page v Hudson 1880 Kotzé 229 (Oct 1880); D’Arcy v Skinner \& Green 1880 Kotzé 231 (Nov 1880); Haesant v Becker \& De Vries 1880 Kotzé 236 (Dec 1880); Celliers v Queen 1881 Kotzé 237 (Apr 1881; in this case, De Wet and Kotzé gave separate judgements; the case concerned the jurisdiction of the landdrost courts); Don v Erasmus 1881 Kotzé 254 (Apr 1881); and Zeiler v Hollins \& Holder 1881 Kotzé 255 (Apr? 1881).

69 Kotzé 1934: 716.

70 Schulze 2010: $111 \mathrm{n} 65$ and the sources cited there.

71 Idem at 115.

72 Idem at 117.

73 On the duties of the Attorney General at the time, see Kruger 1975:22-24.

74 For more on Ford in general, see Smith \& Cunningham 1987.

75 Roberts 1955: 177 n 15; Kew 1979: 76. 
the discovery of diamonds at Kimberly, he moved there during the early 1870 s and is credited with being only the second person to use steam power for washing diamonds, and for building the largest diamond-washing machine at the time.

By coincidence, he met John Kotzé in April 1877 when they shared the same mail coach to Pretoria. ${ }^{76}$ They instantly became friends. This friendship would soon also benefit Ford's career. Kotzé recounted that Shepstone had to urgently appoint an acting Attorney General in Jorissen's absence. Due to the position only being temporary, "no suitable member of the bar from outside the Transvaal was available for a mere acting appointment" and "Shepstone's choice was limited to the selection of one of the local practitioners". ${ }^{77}$ When asked by Shepstone for suggestions for suitable candidates, Kotzé - having been in Pretoria only three weeks and not yet having had the "opportunity of judging the individual capacity of these local men" proposed Ford, and explained that "since he was an Attorney of the Cape Colony ... he would probably have a working knowledge of the practice and routine connected with public prosecutions". ${ }^{78}$ This suggestion was favourably received and Ford was appointed as acting Attorney General in May $1877 .{ }^{79}$ This appointment drew some criticism from Cape Town and Kimberley. However, Shepstone seems to have been satisfied with the quality of Ford's work, ${ }^{80}$ and Kotzé remembered that Ford "did his duty satisfactorily" ${ }^{81}$ As part of his duties, Ford participated at the opening of the High Court described above, and would also later act as judge on two occasions. ${ }^{82}$

76 Kotzé 1934: 424 n 1.

77 Idem at 424.

78 Ibid.

79 He accepted his appointment on 18 May 1877: see TAB SS 237 R1936/77. He had applied for admission as attorney, notary and conveyancer a few days earlier, on 14 May: see TAB SS236 R1843/88. For the Board of Examination's confirmation that he met the requirements for admission, see TAB SS 236 R1880/77 (dated 18 May 1877).

80 Kew 1979: 76-77.

81 Kotzé 1934: 424

82 The first occasion was on 5 Jul 1877, when Kotzé was delayed on his way back to Pretoria with his family: see n 37 supra. It was decided that Ford, in his capacity as acting Attorney General, would hear only the urgent cases, and that all others would be postponed until the next sitting of the court on 12 Jul. Even before the sitting on 5 Jul 1877, one "important criminal case had been finally withdrawn and another [had] been transferred to the Circuit Court of Middelburg": see 27 Jun 1877 De Volksstem. Nevertheless, during the sitting on 5 Jul 1877, the court heard a number of cases: it fined four jury members for not responding to their call for jury duty; it postponed a motion for confirming a rule nisi in Durham v Fleischmann (see n 31 supra), because the respondent's representative, advocate De Vries, objected that his client had not received sufficient notice; and it declined to confirm a motion for a rule nisi in Van der Berg $v$ Rathbone for technical reasons. In the latter case, Adv De Vries, representing the respondent, objected that the notice of motion had been signed by Hollard and Keet, "who are no Attorneys of this Court, while it was served by the deputy Sheriff, appointed by a gentleman who is no Sheriff". He also objected to the notice not having been served in time. Advocate Preller, on behalf of the applicant, argued that, in accordance with the relevant Volksraad resolution, Hollard and Keet could appear, but not 
He also proposed the formal toast at the dinner held for Kotzé by the members of the Bar and Side Bar on 26 July 1877, and proposed "the toast of the evening" to Kotzé in his official capacity, expressing the wish that there would soon be a three-judge court, with Kotzé as Chief Justice. ${ }^{83}$

However, his friendship with Kotzé suffered when the latter found out about Ford's "misplaced ambition of being raised to the Bench later on" ${ }^{84}$ Ford became increasingly reluctant to step down as acting Attorney General, and tried to convince Shepstone that he should instead be appointed on a permanent basis in the place of Jorissen, alternatively that he (Ford) be appointed as a puisne judge..$^{85}$ Kotzé indicated his disillusionment with Ford on a personal level. While they had been good friends after their arrival first in Pretoria, and had even shared an apartment in Pretoria before their families arrived, the friendship soured, and the Kotzé family decided to ignore the Fords, not even greeting them in public. ${ }^{86}$ On a collegial level too, Kotzé expressed his unhappiness during the first half of 1878 by pointing out from the bench the grave breaches of professional etiquette by Ford's office, and eventually granting a rule nisi, ordering Ford to "show cause why he should not be suspended or struck off" the roll. ${ }^{87}$ Nevertheless, Ford remained in his position as acting Attorney General until 3 January 1878, when Jorissen returned and resumed his position. ${ }^{88}$

charge any fees, and that the applicant was not answerable for the fact that the government had not yet officially appointed a deputy Sheriff. After some discussion, the court refused the motion with costs, because although the notice had been served in time, it had not been duly certified. The court also admitted three practitioners, namely TM Siddal as attorney (later sworn in in chambers), as well as DB Naudé and C Ueckermann as advocates and attorneys (later to be sworn in at Zeerust and Heidelberg respectively). Further, a criminal case against one Conradie was postponed, and he was advised to select counsel to represent him - he selected Adv De Vries, and Francois Zeiler as his attorney. See, generally, 11 Jul 1877 De Volksstem. The newspaper lamented the "confusion of languages", as both Advs De Vries and Preller argued their cases in Dutch, while the presiding judge (Ford) ruled in English. The journalist opined that this was "calculated to enhance the dignity of the judicial procedure", but suggested that, in future, the parties should agree on the language in which a case should be heard beforehand. I could not find details of the second occasion on which Ford acted as judge; if he did do so, Kotzé did not consider the judgement worth reporting.

831 Aug 1877 De Volksstem.

84 Kotzé 1934: 424-425 relates that he had heard this from none other than the Colonial Secretary at the time, Melmoth Osborn, who told him that Ford was of the opinion that when his term as acting Attorney General came to an end upon Jorissen's return, he "had a claim on the Government in the above direction". Kotzé was not impressed and pointed out to Osborn that Ford "had no claim whatever to a seat on the Bench". See, also, Kew 1979: 78.

85 Kew 1979: 78 esp n 8.

86 Idem at 77-79.

87 Idem at 79 esp nn 15 and 16.

88 Idem at 78 esp n 10. 
After the First Anglo-Boer War, Ford continued his legal practice at Pretoria. ${ }^{89}$ Of the cases reported for the period from 1877 to 1881, Ford appeared in twentytwo, of which only four was in his capacity as acting Attorney General. ${ }^{90}$

After gold was discovered on the Witwatersrand in 1886, he became one of the founders of Johannesburg and helped to peg out the city. He was one of the partners of the Randjeslaagte Syndicate, and later went into partnership with the Jeppe family. The suburb Fordsburg is named after him. He was also involved in the establishment of the Pretoria Electric Lighting Company. For health reasons, he gave up his practice in 1888, and eventually moved back to England the following year. He resumed business in London in 1896 and was involved in mining enterprises in East Africa.

Ford was married four times and had children from each marriage. He befriended the writer Rider Haggard - probably during their time together as judicial officers in Pretoria (more on him below) - who was the godfather to one of his sons. Ford died in London on 12 December 1925.

\section{Eduard Johan Pieter Jorissen ${ }^{91}$}

Jorissen was born in Zwolle, in the Netherlands, on 10 June 1829. He never received any formal legal training, except for his three months' study before sitting for the

89 Smith \& Cunningham 1987: 272. Nathan 1932b: 40 mentions that he had a "large civil practice".

90 As acting Attorney General, he appeared in Attorney-General v Skinner 1877 Kotzé 4 (Oct 1877); In re Phelan 1877 Kotzé 5 (Nov-Dec 1877); In re Roselt \& Inglis 1877 Kotzé 13 (Dec 1877; representing the minor); and Muller v Coppen 1878 Kotzé 16 (Feb 1878; although the report does not explicitly mention that Ford acted as Attorney General in this case, it concerned the setting aside of an arrest warrant). He also appeared as legal representative in the following cases: Cape Commercial Bank v Fleischman \& Van Rensburg 1877 Kotzé 1 (Jul 1877); Zeiler v Weeber 1878 Kotzé 17 (Mar 1878; with De Vries, for the judgement creditor); Leathern v Henderson 1878 Kotzé 46 (Jun 1878; for the attorney of the executors); Weatherley $v$ Weatherley 1878 Kotzé 66 (Nov 1878-Jan 1879; with De Vries, for the defendant); Van Rensburg v Swart 1879 Kotzé 99 (Jan 1879; with Jorissen, for the defendant); Barrett v Executors of O'Neil 1879 Kotzé 104 (Feb, May 1879; with Preller, for the defendants); Brodrick v Leathern 1879 Kotzé 139 (Jul 1879; for the applicant); Leathern v Brodrick 1879 Kotzé 143 (Jul 1879; for the defendant); Cape Commercial Bank v Schröder \& Co 1879 Kotzé 161 (Nov 1879, Jan 1880; for the defendants; Attorney General Maasdorp represented the plaintiff); Baker v Saunders 1880 Kotzé 176 (Mar, Jul 1880; for the respondent); McHattie v Twycross 1880 Kotzé 190 (Jun 1880; with Innes, for the respondent); Welsh v Bernhard, Cohen \& Co 1880 Kotzé 192 (Jun 1880; for the plaintiff); Twycross v McHattie 1880 Kotzé 198 (Jul 1880; assisting Cooper, for the applicant; it appears that Ford felt it necessary to call in assistance in this case as Cooper offered the main arguments on behalf of the client; in this matter, the respondent had three representatives); Cooper v Jocks 1880 Kotzé 201 (Jul, Aug 1880; with Cloete, for the plaintiff); Coventry Brothers v Kingsmill 1880 Kotzé 203 (Jul, Aug 1880; assisting Cooper, for the plaintiffs); Municipality of Potchefstroom v Cameron 1880 Kotzé 206 (May, Jun, Sep 1880; assisting Preller, for the defendants); Du Toit v Hudson 1880 Kotzé 220 (Aug 1880; with Preller, for the plaintiff); and Page v Hudson 1880 Kotzé 229 (Oct 1880; assisting the Attorney General, Morcom, for the defendant).

91 See, in general, Ploeger 1972: 344-374; Roberts 1942: 366; Kruger 1975: passim. 
Transvaal Bar examination in $1876 .{ }^{92} \mathrm{He}$ had originally trained as a theologian at the Rijksuniversiteit in Utrecht and received his doctorate in theology from the University of Groningen in $1876 .{ }^{93} \mathrm{He}$ had been a minister of various congregations and authored several theological works, before accepting President Burgers' offer to become a lecturer in classical languages at the still-to-be-built gymnasium (high school) in the Transvaal at an annual salary of $£ 400 .{ }^{94}$ Upon his arrival in South Africa, however, and after consultation with the Transvaal consul in Cape Town, JR Marquard, ${ }^{95}$ Jorissen realised that his philosophical and theological views, as well as the limited opportunities in education in the then Transvaal, necessitated his changing careers as soon as possible. ${ }^{96}$ It was at this point that he commenced with his legal studies, ${ }^{97}$ and after passing the examination, ${ }^{98}$ he was appointed as

92 Wildenboer 2011: 350 esp n 86.

93 Kruger 1975: 6.

94 See British Parliamentary Papers 1971: 486, C 2891 Despatch Lanyon to Earl of Kimberley, dated 1 Feb 1881 at 486. Kotzé 1934: 355 n 1 points out that the popular misconception, namely that Jorissen came to the Transvaal after being offered the post of Superintendent General of Education, was due to Theal's incorrect reporting: see Theal 1919 vol 1:254-255. Kotzé correctly states that it was actually Van Gorkom who was appointed to this position: see, also, Jorissen 1897: 4; Jorissen was offered and had accepted the position as lecturer in classical languages, although he changed careers when he finally arrived in the Transvaal: see Jorissen 1897: 4; Roberts 1942: 366. Wilhelm Johan van Gorkom (1827-1888) was born in the Netherlands and had several years of experience in education before accepting President Burgers' offer of becoming the first Superintendent of Education of the Transvaal. He arrived in Pretoria on 6 Feb 1876 and took up office a few days later on the 15th. Apart from his efforts to develop the educational system, he was also instrumental in establishing a museum, a library and a botanical garden. He resigned from his position in Mar 1878 due to his refusal to apply new governmental regulations. He then returned to the Netherlands, where he continued his career in education. He had not been popular among the Boers in the Transvaal due to his liberal views, nor did he fully fit in with the British governmental officials. For more on Van Gorkom, see Ploeger 1977b: 825-826.

95 Marquard accepted his appointment as Transvaal consul in a letter dated 31 Jan 1874: see TAB SS 168 R239/74. Jorissen 1897: 6 and 7 describes him as "een statige figuur" (a dignified figure) and as "een type van het oude ras der werkelijk aristocratische Kapenaars, eenvoudig van manieren, met iets afgemetens, maar gastvrij, beleefd en hulpvaardig" (one of the old race of truly aristocratic Capetonians, simple in manner, with some dignity, but hospitable, polite and helpful).

96 Jorissen 1897: 6-7. It was Marquard who gave him the idea to apply for the position of Attorney General, since Buchanan had shortly before visited Cape Town on his way to Bloemfontein after resigning from that post: see $\mathrm{n} 99$ infra.

97 On his way to Pretoria from Cape Town, he studied the works of the old Roman-Dutch law authors, which were authoritative sources of law in the Transvaal. (For more on the authoritative sources of law of the ZAR, see Wildenboer 2015: 465-468.) In particular, he studied Van Leeuwen's Rooms-Hollandsche Recht, Van der Linden's Koopmanshandboek and Grotius' Inleidinge: see Roberts 1955: 177. He also consulted Buchanan, Roth (the then public prosecutor in Pretoria) and Swart (the then acting Attorney General). He further attended court sessions to listen to the legal arguments of Stephanus Meintjes, Maurits de Vries and Jan Preller: see Jorissen 1897: 8-9. Jorissen arrived in Pretoria on 6 Feb 1876. For his application to sit for the examination, see TAB SS 208 R1031/76 (dated 30 Apr 1876). He sat for his law examination before a panel consisting of Meintjes, De Vries, Preller, I Munnich and Nicolaas Jacob Reinier Swart (for more on him, see n 98 infra), the latter at the time being acting State Attorney before the annexation. See Jorissen 1897: 10; Nathan 1932a: 13.

98 For the panel's confirmation that Jorissen had been examined, see TAB SS 209 R1347/76 (dated 6 Jun 1876). 
State Attorney (the post was renamed as Attorney General after annexation) on 9 June $1876 .{ }^{99} \mathrm{He}$ condemned the 1877 annexation and was one of the two-member delegation (the other being Paul Kruger) who traveled to London in May of that year. ${ }^{100}$ It was during this absence that Ford was appointed as acting Attorney General. On his return from England, Jorissen resumed his position as Attorney General on 3 January 1878. Of the cases reported between 1877 and 1881, he appeared in nine, of which only three were in his capacity as Attorney General. ${ }^{101}$

However, his lack of formal legal training and insufficient legal experience was not consistent with Kotzé's vision of a fully qualified Bar and bench, ${ }^{102}$ and ten months after he had resumed this position, Jorissen was replaced with Christian Maasdorp, due, at least partially, to Kotzé's involvement. ${ }^{103}$ The latter had on three

99 And not on 9 Jul 1876 as per Ploeger 1972: 345: see Jorissen 1897: 10. He took the oath as Attorney General on 10 Jun 1876: see TAB SS 209 R1416/76 (dated 10 Jun 1876). See, also, TAB SP 5 SPR1841/76 (dated 10 Jun 1876) for Swart's letter confirming Jorissen's appointment. Jorissen succeeded James Buchanan, who had resigned in Nov 1875; in the intervening months, Swart had acted as State Attorney: see n 97 supra. For more on Buchanan, see Moll 1972: 95-96; Roberts 1942: 351. Buchanan (1841-1893) commenced legal practice in 1865 . He took office as State Attorney of the Transvaal on 9 Dec 1872, but he found the Transvaal mindset and way of life oppressive, and resigned three years later to become a puisne judge of the Supreme Court in the Orange Free State. For more on Swart, see Spoelstra 1968: 817-818. Swart (1831-1892) was born in the Netherlands, and arrived at the Cape in 1849. He had no legal training. He had tried his hand at farming and teaching before he commenced theological studies. In 1866 he became the first minister of the Reformed Church in Pretoria. However, on his return to Pretoria after a visit to the Netherlands, he announced, to public outcry, that he no longer wanted to serve in the ministry and instead accepted the post as governmental secretary. He left Pretoria and moved to the Cape, eventually settling in Mossel Bay.

100 Leyds 1906: 271-272. See, also, n 28 supra. For Jorissen's memories of this journey, see Jorissen 1897: 36-37.

101 As Attorney General he appeared in the following reported cases (I have added the dates and additional information to each citation): Queen v Saul, Rooikraal and Saul 1878 Kotzé 32 (Mar 1878); Ex parte Lithauer 1878 Kotzé 38 (Apr 1878); and Breytenbach v Queen 1878 Kotzé 55 (Aug 1878). He also appeared as legal representative in the following cases: Van Rensburg $v$ Swart 1879 Kotzé 99 (Jan 1879, assisting Ford, for the defendant); Queen v Potts 1879 Kotzé 115 (Mar 1879; for the accused; Attorney General Maasdorp prosecuting); Ferguson v Pretorius 1879 Kotzé 157 (Nov 1879; with Cloete, for the defendants); Ex parte Bok 1880 Kotzé 167 (Jan 1880; for the applicant); Jacobs v Queen 1880 Kotzé 178 (Mar 1880; for the accused; Attorney General Morcom prosecuting); and Ex parte Bok 1880 Kotzé 223 (Aug 1880; with Cooper, for the applicant).

102 See Kotzé 1934: 529-540; at 540 he emphasised that Shepstone at no point discussed the matter with him directly. On this latter aspect, see also Kruger 1975: 106-107. Kew 1979: 80 speculates that Kotzé was worried that the government's blind eye to Jorissen's lack of training in retaining him as Attorney General might later lead to his being raised to the bench (which indeed happened when Jorissen was appointed judge in 1890: see the text to n 112 infra). Also, Kotzé did not want the standard of the Transvaal judiciary to be lowered by an unqualified Attorney General.

103 See Kruger 1975: 97-105 regarding the reasons for and the events leading up to Jorissen's dismissal. See, also, Kew 1979: 81-83, who considers the evidence and then concludes that Jorissen's dismissal was due not only to Kotzé's strong views on his lack of training, but also to Shepstone's preference for an Attorney General with confirmed British loyalties. 
occasions commented in public on Jorissen's competence, twice in open court. ${ }^{104}$ Shepstone had offered Jorissen the position of landdrost of Pretoria, with the same salary as that of the Attorney General, but Jorissen declined. ${ }^{105}$ After his dismissal, Jorissen remained at the Bar and practised as a dual-capacity lawyer. ${ }^{106}$

Jorissen became increasingly involved in politics, and traveled to Cape Town with Kruger and Piet Joubert in early 1880 to contest the proposed plans for the federation of the southern African territories under British rule. In December 1880, Jorissen became a member of the Boers' Executive Council and later played a crucial role in the peace negotiations and the signing of the subsequent Pretoria Convention on 3 August 1881. On 8 August he was re-appointed as Attorney General of the restored Republic. ${ }^{107}$ However, in July 1883 he was again dismissed from this post on the grounds of incompetence, and once again Kotzé, this time with the support of SJ du Toit, the then Superintendent of Education, ${ }^{108}$ had a hand in

104 Kew 1979: 80-81. The first case was that of Barrett $v$ The Registrar of Deeds and Holtzhausen (unreported, cited in Kew 1979: 80 n 18), in which Kotzé criticised Jorissen for a conflict of interests when he appeared for the opposing side after he had already given Barrett a legal opinion for which he had received payment. The second case concerned an arrest warrant issued by Jorissen without his taking cognisance of the relevant procedures stipulated in Ord 5 of 1871; Kotzé couldn't help commenting from the bench that Jorissen's professional oversight and his role in the unlawful arrest would impact on the reputation of the legal profession of the Transvaal. The third occasion was during a public address to the inhabitants of Potchefstroom in May 1878, when Kotzé remarked that the Attorney General, as head of the Transvaal Bar, should have the same qualifications as a judge.

105 Kotzé 1934: 533.

106 Wildenboer 2011: $351 \mathrm{n} 89$.

107 See n 88 supra.

108 For Du Toit's part in Jorissen's dismissal, see Kruger 1975: 250-255. For more on Du Toit in general, see Anonymous 1968: 279-283. Stephanus Jacobus du Toit (9 Oct 1847-28 May 1911) was born and died at Dal Josafat in the Paarl. His father, a wine farmer, was a direct descendent of the French Huguenot, Francois du Toit. SJ received his basic education at the Paarl Gymnasium, where after he studied theology at the Stellenbosch seminary. He became a proponent of the Dutch Reformed Church in 1872, and a minister of the same church in 1875 . He served in the ministry until 1881, when he accepted the offer as the Transvaal Superintendent of Education. He had strong political views and was not afraid to voice them. During his time in Pretoria, he became an advisor to Paul Kruger, and was a member of the delegation that signed the London Convention on behalf of the Transvaal government in 1884 . However, he became increasingly opposed to the Dutch influence in South Africa; his increasing criticism of Kruger's government made him unpopular, and in 1888 he resigned as Superintendent of Education. He returned to the Paarl in 1890, where he continued his theological work and his writing. He is best known as a campaigner for Afrikaans as an independent language and was involved in the establishment of the Genootskap van Regte Afrikaners in 1875, and for the establishment of the first Afrikaans newspaper, Die Afrikaanse Patriot, the next year. He published widely on theology, and on political and linguistic matters. In 1896 he established the first Afrikaans literary magazine, Ons Klyntji. He was married twice: first to Elizabeth Jacoba Joubert, and after her death to Anna Francina Malan. Four children were born of each marriage. In 1910, while en route to Calvinia, his horse cart overturned and he sustained serious and ultimately fatal injuries. 
this. ${ }^{109}$ Jorissen then resumed practice at the Pretoria Bar as an advocate, ${ }^{110}$ until he was appointed as special judicial commissioner with the powers of a magistrate in 1888 to assist with the backlog of civil cases at the time. ${ }^{111}$ In 1890 he was appointed a criminal judge of the High Court, this time with Kotzé's approval. Nathan ${ }^{112}$ mentions the time when Jorissen, on Circuit Court in Johannesburg, presumably for reasons of saving public money, started court proceedings at seven in the morning to the disgruntlement not only of prosecuting and defending counsel, but also of members of the jury. However, to appease all present, Jorissen then adjourned the proceedings four hours later "so that those who wished might enjoy a 'schnapps' of 'jenever"." ${ }_{113}$

In 1893, Jorissen was chairman of the commission tasked with revising the ZAR Constitution. He also published a codified version of the laws of the Transvaal, knows as the Codex van de Locale Wetten der Zuid-Afrikaansche Republiek: Eene Proeve, ${ }^{114}$ and in 1895 he received an honorary doctorate of laws from the University of Groningen. During the constitutional crisis, ${ }^{115}$ he opposed Paul Kruger's views on the testing abilities of the Transvaal courts. During the final years of his legal career, he attracted criticism for lack of self-control in the performance of his judicial duties, ${ }^{116}$ culminating in the press calling for his dismissal due to incompetence. ${ }^{117}$

Jorissen was also involved in political affairs, and endeavoured to bring about Transvaal-Dutch co-operation. This, together with his liberal theological views, his outspokenness, ${ }^{118}$ his temperamental personality and his apparent lack

109 See Hiemstra 1968: 459, who points out that Kotzé and Du Toit had different motives for wanting to oust Jorissen: Kotzé, because he wanted a better qualified candidate in the post, and Du Toit, because he did not agree with Jorissen's liberal theological views and because Jorissen was Dutch. However, Roberts 1955: 183 argues that the reason for the dismissal was really for financial considerations: the new requirement that the Attorney General should in future be appropriately qualified, meant that the annual salary for the position was raised from $£ 600$ to $£ 1000$. For Jorissen's resentment of Kotzé and Du Toit for their part in his dismissal, see Jorissen 1897: 127130.

110 For more on Jorissen's work as advocate during this time, see Kruger 1975: 345-347.

111 See Kruger 1975: 347-353. Between 1 Oct 1888 and 19 Feb 1890 Jorissen finalised around 700 cases. See Kruger 1975: 348 and 350.

112 Nathan 1932b: 40.

113 For more accounts of Jorissen's eccentric behaviour in court, see Roberts 1955: 185-186.

114 It was published in 1894 in Groningen by Van der Kamp. For more on Jorissen's Codex, see Kruger 1975: 364-369.

115 See $\mathrm{n} 51$ supra.

116 Nathan 1932b: 40 mentioned the "exceedingly bitter passages of arms" exchanged in court between Jorissen J and Andries Maasdorp in the unreported case of Van der Hoven v Robinson, in which Maasdorp represented the plaintiff. Nathan speculated that this enmity might not entirely have been directed at Maasdorp personally, but rather at his client, Van der Hoven, since "the Judge seemed to be animated by an equally strong feeling against the plaintiff".

117 See Kruger 1975: 422.

118 An example of his outspokenness from the Bench is his remark to the accused in a trial held during the Barberton Circuit. The accused, an official, had been charged with peculation, but had been acquitted by the jury despite strong evidence against him. Before discharging the official, Jorissen expressed his views on this matter by addressing him as follows: "When you say your prayers tonight - if you do say them - go down on your knees and thank God that you have been tried by a Barberton jury." See Nathan 1932b: 40. 
of tact, brought him in conflict with some of his peers and contributed to his unpopularity. ${ }^{119}$

In 1907 he returned to the Netherlands and died at Scheveningen on 20 March 1912. During his last years he was plagued by mental instability. He was married to Anna Catherina Elisabeth van Eyk, and two daughters and three sons ${ }^{120}$ were born of the marriage.

\section{Christian George Maasdorp ${ }^{121}$}

Maasdorp was born in Malmesbury in the Cape on 11 June 1848. He was the younger brother of, and should not be confused with, Andries Maasdorp. ${ }^{122} \mathrm{He}$ received his

119 In 1896, Jorissen was sued for libel by a member of the Executive Council, PJ Joubert, after Jorissen had, in public, addressed Joubert with the following: "General Joubert, are you aware that your son-in-law, Malan, is in collusion with the rebels of Johannesburg? If so, you are guilty of treason, and you ought immediately to resign your position." In the magistrate's court of Pretoria, Jorissen then raised the exception that his words were not libellous, but the exception was overturned by the magistrate. On appeal, the court (presided over by Kotzé) found the words not libellous and without innuendo against Joubert: see EJP Jorissen $v$ The State (1896) 3 Off Rep

153. Despite the court's finding, this incident certainly could not have made Jorissen popular, at least not in governmental circles.

120 Most relevant for purposes of this article is Samuel Gerhard Jorissen (10 Mar 1857-3 Sep 1889), who had also been a judge of the Transvaal Supreme Court until his untimely death at the relatively young age of thirty-two. Samuel was the eldest son of EJP, and was born on Kampereiland, the Netherlands. He received his basic education in Groningen, and obtained his doctorate in public international law in 1880 at the University of Groningen. In 1881 he arrived in the Transvaal, where he was admitted as an attorney and advocate. He practiced law with Dr FB Tobias in Pretoria from 1882. In 1886, he was appointed as commissioner for the Western Districts Court for Potchefstroom and Christiana. In the same year he was appointed as second criminal judge of the Transvaal. He received acclaim for his minority judgement in favour of the testing abilities of the courts in the matter of Trustees in the Insolvent Estate of Theodore Doms v Bok No (1887) 2 SAR 189, while Kotzé CJ and Esselen J confirmed the validity of the Volksraad decision in question. To the question whether a Volksraad resolution has the force of law, Jorissen fils argued that "[s]uch Resolution alone is as yet no law; publication and proclamation are still required" (at 200) and that "a resolution that has not been passed in the prescribed manner cannot bind the judge, who is only bound to act in accordance with the laws" (at 201). He then applied the requirements for the promulgation of a law to the Volksraad resolution in question (R 2697 of 3 May 1887) and found that "[a]s a law, taking away the rights of plaintiffs, the resolution ... has, in my opinion, no force, as it is informal" (at 203). See, also, Van der Merwe 2018a: 107-112; Hiemstra 1968: 459460. As a result, Jorissen fils was tasked with the review of the 1858 Constitution. His suggestions were accepted in 1889. Samuel married Mary Adelene Burgers, the third daughter of former President Burgers, but no children were born of this marriage. He died of malaria. See, in general, Ploeger 1977a: 467-468.

121 See, in general, Van Warmelo 1987: 479-480; Roberts 1942: 370.

122 Andries Ferdinand(us) Stockenström Maasdorp (1847-1931) was the second of the five Maasdorp brothers, and older than Christian by seventeen months. He was a brilliant student and received an award while still at school in Graaff-Reinet for being the top student in the Cape for both mathematics and classical languages. He continued his studies at the Graaff-Reinet College and in 1869 obtained a BA degree from the University College in London. He was admitted as an advocate at the Inner Temple on 17 Nov 1871. The following year he started practicing at the Cape Bar; he also represented his home town, Graaff-Reinet, in the legislative assembly. From 1878 to 
basic education at Graaff-Reinet and obtained both the Second-Class (1867) and First-Class (1868) Certificates in Literature and Science from what would later be known as the University of the Cape of Good Hope. ${ }^{123} \mathrm{He}$ then continued his studies in London, where he obtained the BA degree in 1869. Thereafter he became a member of the Inner Temple, where he was a fellow student of Kotzé. ${ }^{124}$ The latter fondly remembered meeting the two Maasdorp brothers at a dinner hosted by the Reverend Hoets, ${ }^{125}$ and described that as the start of a "life-long friendship" with Christian Maasdorp.

Maasdorp was admitted as a barrister on 6 June 1871. He then returned to South Africa and was admitted to the Cape Bar on 3 August 1871. He practised at the Supreme Court of Griqualand West at Barkly West and thereafter at the Supreme Court of the Eastern Districts in Grahamstown, before being appointed as Attorney General of the Transvaal on 1 October $1877 .{ }^{126} \mathrm{He}$ resigned ${ }^{127}$ from this position in February 1880 and returned to Cape Town to resume practice there. During his term as Attorney General, he appeared in twelve of the reported cases. ${ }^{128}$

1896 he served as Attorney General of the Eastern Districts. In 1890, he became Queen's Counsel. In 1897 he moved to Pretoria, where he joined the Pretoria Bar. In the later constitutional debate between Kotzé en President Kruger, Maasdorp sided with Kotzé. Just before the outbreak of the Second Anglo-Boer War, he returned to Grahamstown, where he resumed legal practice. During the War, he served as member of the special court hearing treason trials. In 1902, he was appointed Chief Justice of the Orange Free State and later Judge President of that province. He was knighted in 1904. He published an English translation of De Groot's Inleidinge (The Introduction to Dutch Jurisprudence (1878), of which the second and third editions also included Schorer's notes). Although he wrote a few other legal works, he is best known for his Institutes of South Africa (first published in 1903 with multiple later editions). He was married to Agnes Hayton, with whom he had three sons. He has been praised for his legal skills, especially that of cross examining, and has been described as gifted, with a strong personality and as easy going. For more on Andries Maasdorp, see Van Tonder 1968: 504-505; Roberts 1942: 370.

123 See, also, Kew 1979: 83 esp n 33.

124 Kotzé 1934: 199.

125 Idem at 106. Hoets was South-African born, but had studied at Cambridge and had retired as a minister of the church. At the time of this particular dinner, he was living in St John's Wood, London.

126 Idem at 540 mentioned that Maasdorp settled in quickly due to his being bilingual, and because he grew up in Graaff-Reinet. He described Maasdorp as "[c]alm, solid and unassuming".

127 In his official capacity, Maasdorp had to prosecute MW Pretorius (a former president of the ZAR) and Bok for treason. According to Kotzé 1934: 672, Maasdorp chose instead to resign from his position as this obligation did not sit well with him, and because he was not willing to "help Wolseley [the British administrator at the time] make slaves of [his] countrymen".

128 Dore v Meintjes 1879 Kotzé 101 (Feb 1879; with Meintjes, for the respondent; the case concerned an interdict for diverting water); White \& Tucker v Rudolph 1879 Kotzé 115 (May 1879; this case concerned an interdict served upon the landdrost of Utrecht in his official capacity; Cooper and Cloete appeared for the applicants); White \& Tucker v The Administrator 1879 Kotzé 127 (May 1879; for the Crown; Cooper and Cloete again for the applicants); Van Blerk v Hollins \& Holder 1879 Kotzé 128 (Jun 1879; this case concerned an application that the plaintiff provide security for costs); De Hart v Steyn 1879 Kotzé 132 (Jul 1879; with Hollard, for the appellant; this case was an appeal from a decision by the landdrost of Pretoria and concerned the admissibility of evidence given at Bloemfontein); Rudolph v White \& Tucker 1879 Kotzé 135 (Jul 1879; for the 
In later years, Maasdorp would be Judge of the Supreme Court of the Eastern Districts (from 1885); Judge of the Cape Supreme Court (from 1896); and Judge President of the Cape Division of the Supreme Court, as well as Judge of Appeal (from 1910). He has been commended for "the clarity of his thinking and his logical argumentation". ${ }^{129}$

He retired in 1922 and died in Grahamstown on 21 May 1926. He was married to Ella Elizabeth Hutton and had six children, two of whom were killed during the First World War.

\section{William Boase Morcom ${ }^{130}$}

Morcom was born in Cornwall, England, on 9 October 1846. He received his basic education in England before accompanying his father to South Africa in 1861. In Pietermaritzburg, he worked for the press from 1866 while studying law in his spare time under $\mathrm{MH}$ Gallwey ${ }^{131}$ and $\mathrm{H}$ Bale. ${ }^{132} \mathrm{He}$ then took up various governmental

Crown; this was an application for leave to appeal to the Privy Council); Gouws v Queen 1879 Kotzé 141 (Jul 1879; for the Crown); Stamp v Rex 1879 Kotzé 147 (Oct 1879; with Preller, for the state; the case concerned a claim for damages in terms of a cancelled lease contract of three mills, a wool washery and a dwelling house); Curator of Van der Merwe's Estate $v$ Van der Merwe 1879 Kotzé 148 (Jul, Nov 1879; with Meintjes for the plaintiff; this concerned a dispute regarding certain marital assets in an insolvent estate); Van der Merwe v Turton \& Juta 1879 Kotzé 155 (Jul, Nov 1879; with Meintjes, for the defendants; this involved a claim for damages based on the wrongful seizure and sale in execution of certain property); Compton v Williams 1879 Kotzé 160 (Nov 1879; for the plaintiff; this was an exception that the summons was based on an illegal account charging compound interest); and Cape Commercial Bank v Schröder \& Co 1879 Kotzé 161 (Nov 1879, Jan 1880; for the plaintiff; this concerned the locus standi of the plaintiff).

129 Van Warmelo 1987: 480.

130 See, in general, Leverton 1972c: 494.

131 See, in general, Leverton 1977: 323-324; Roberts 1942: 361. Michael Henry Gallwey (18261912) was born in Greenfield, Clonakilty, Cork, Ireland. He received his education at Trinity College in Dublin and obtained a BA degree in 1851. In 1853 he was admitted to the Irish Bar through King's Inn. Later that same year he emigrated to Natal, where he commenced his legal practice. In 1857 he became the youngest-ever colonial Attorney General of Natal to date. In this capacity, he was also a member of both the Executive and the Legislative Councils. He was opposed to the idea of responsible government. While he was Attorney General, he also maintained his own legal practice and took many up-and-coming young attorneys under his wing. In 1890, he was appointed as Chief Justice of Natal, which he retained until his retirement in 1901. During his career he also served in various other capacities, namely as member of the Natal Education Council, as advocate for the Admiralty and as chairman of the border commission tasked with the setting of the Transvaal/Zululand border. He was knighted twice, in 1883 and in 1888. Gallwey was a gifted speaker and he had the ability to remain patient, even when provoked. These abilities served him well throughout his career. In 1862 he married Fanny Cadwallader Erskine and five children were born of the marriage.

132 See, in general, Leverton 1972a: 23-24; Roberts 1942: 347. Henry Bale (1854-1910), a native of Natal, was born and died in Pietermaritzburg. He received his basic education at the Pietermaritzburg High School and thereafter at the Exeter Grammar School in England. Health reasons prevented him from attending university. He completed his articles with a Pietermaritzburg law firm, and was admitted as attorney in 1875, and as advocate of the Natal Bar in 1878. He 
positions, namely that of assistant clerk and shorthand writer (1872) and later clerk (1873) to the Natal Legislative Council; as general factotum to Sir Garnet Wolseley (1875); as clerk to the Natal Governor (1875); as clerk to the Natal Executive Council (1875); and as clerk to the Natal Attorney General (1876). He accompanied Shepstone to the Transvaal in 1877 as his private secretary, legal adviser and financial confidant. He was appointed as the Transvaal Attorney General on 12 February $1880 .{ }^{133}$ The members of the Bar resented his appointment and "considered themselves slighted by the placing over their heads of a new importation". ${ }^{134}$ Kotzé was not impressed with the appointment of "a person without proper qualification" either. ${ }^{135}$

During his time as Attorney General, Morcom appeared in nine reported cases. ${ }^{136}$

practiced in Pietermaritzburg and took silk in 1897. In 1890 he became a member of the Natal Legislative Council. He opposed responsible government. He was twice offered the premiership of Natal (in 1897 and in 1899), but declined on both occasions. Instead, he accepted the position of Attorney General in 1897. He succeeded Gallwey as Chief Justice of Natal in 1901 and remained in that position until his death. He was also interested and involved in educational affairs. Bale was known for his good judging of character, for his patience and for his ability to concisely and logically summarise a position. These abilities served him well as Chief Justice. Although he was sympathetic, he has also been described as knowing "how to dispense real and effective justice in dealing with undoubted offenders". Bale was knighted in 1901. He was married twice, first to Eliza Wood (1880) and later to Margaret Berning. No children were born of either marriage.

133 On Morcom, Jorissen 1897: 38 sarcastically remarked the following: "Hij heft groote diensten aan de Republiek bewezen. Ik durf zeggen onbedoeld. Een jong mensch, zonder eenige de minste politieke ervaring, uiterst geschikt om acte's van Beschuldiging op te trekken, heft hij met voorbeeldigen ijver den Administrateur der Transvaal advise gegeven, welke de verbittering tusschen de Britsche Regeering en de Boeren voortdurend aanwakkerden" (He served the Republic. I must add by accident. A young person, without the least political experience, very suitable to draft indictments, he advised the Administrator of Transvaal with exemplary diligence, which continuously encouraged resentment between the British government and the Boers). However, it should be borne in mind that apart from the fact that Morcom served the British government during the First Anglo-Boer War, Jorissen resented Morcom for a more personal reason as well. Jorissen 1897: 38 mentioned Morcom's letters being intercepted by the Boers during the war, which alerted the Boers to the fact that Morcom intended to prosecute the Boer leaders (Kruger, Joubert, Bok and Jorissen himself) before a special military court after the war.

134 Kotzé 1934: 672-673.

135 Idem at 696-697. Kotzé took offence at the fact that a person who had attended a mere twelve court sessions in three years, and who had been but a clerk in the office of the Natal Attorney General, was appointed as Attorney General of the Transvaal. Once again he feared that this would set a precedent and might induce Morcom to hope for a later promotion to the bench itself. Kotzé complained in writing to the Secretary of State, but the letter was returned to him by the new Administrator, Lanyon, on the basis that Kotzé had signed the letter as "Chief Justice"; Lanyon coolly pointed out that he could not forward the letter since Kotzé was merely a puisne judge. Kotzé was not to be deterred. He responded to Lanyon, and also sent a separate letter containing the correspondence in this regard between himself and Lanyon directly to the Secretary of State. See Kotzé 1934: 698-701. However, his complaint was ignored and Morcom remained in his position until the signing of the Convention of Pretoria.

136 Jacobs v Queen 1880 Kotzé 178 (Mar 1880); Cloete v The Government 1880 Kotzé 175 (Mar 1880; for the Crown); Potchefstroom Municipality v Cameron \& Shepstone 1880 Kotzé 185 (Mar 1880; this case concerned an exception based on a notice published by the Colonial Secretary); Du Toit v Hudson 1880 Kotzé 220 (Aug 1880; with Meintjes, for the defendant in his capacity as Colonial Secretary); Ex parte Hudson 1880 Kotzé 224 (Aug 1880; a case of the arrest of the 
After the Transvaal regained its independence in 1881, Morcom returned to Pietermaritzburg where he became a solicitor, having a special interest in commercial law. He acted as Natal Attorney General in 1885 and was appointed to this position four years later, succeeding his old mentor, M Gallwey. He was made Queen's Counsel in 1888. In the years after his resignation as Attorney General, he again became involved in governmental affairs and was appointed Minister of Justice in 1903. He also served as Member of Parliament for Pietermaritzburg from 1897 until his death, and drafted the federal constitution for South Africa.

Morcom never married and died in Pietermaritzburg on 23 April 1910. He was not popular and has been described as "a poor speaker and a poor statesman" and as "a pedant who regarded the law more important than justice", despite being "the Natal authority on Roman-Dutch law and on international and constitutional matters" ${ }^{137}$ In his private life, he was conservative and critical of drinking and gambling.

\section{Registrars and Masters}

\section{Hendrik Willem van Breda}

Not much is known about HW van Breda. He is not mentioned in any of the usual sources, nor by Kotzé in his memoirs. I found only a handful of references relating to one Van Breda. According to them, he died after a long illness early in $1878 .{ }^{138}$ Since this corresponds with Rider Haggard's recount of the previous Master and Registrar dying shortly after the 1877 annexation, ${ }^{139}$ I assume this is the same person.

In 1874, the State Secretary requested information on HW van Breda from the Transvaal consul, JR Marquard, ${ }^{140}$ in Cape Town. ${ }^{141}$ This response seems to have been reassuring, because on 3 February 1875, Van Breda accepted in writing his appointment as Treasurer General of the Transvaal. ${ }^{142}$ On the day after the annexation, Van Breda wrote to the new government, requesting to remain in his position. ${ }^{143} \mathrm{His}$ request was clearly not taken seriously, because instead he was then appointed as Registrar and Master of the High Court. As mentioned earlier, he was sworn in in

Orphan Master, HC Bergsma, to prevent him from leaving the Transvaal); Page v Hudson 1880 Kotzé 229 (Oct 1880; with Ford, for the defendant in his capacity as Colonial Secretary); Haesant v Becker \& De Vries 1880 Kotzé 236 (Dec 1880; this case involved a promissory note signed by an agent); Celliers v Queen 1881 Kotzé 237 (Apr 1881; with Cloete); and Meintjes v Meintjes 1881 Kotzé 252 (Apr 1881; a provisional sentence regarding martial law).

137 Leverton 1972c: 494.

138 See TAB SS 273 R1006/78 (dated 5 Apr 1878) for the request of the acting executors of his estate (M van Breda and G Weavind) regarding Van Breda's arrear salary.

139 Rider Haggard 1926: 110.

140 See, also, n 95 supra.

141 See TAB SS 181 Supl 7/74 (dated 13 Mar 1874).

142 See TAB SS 183 R284/75.

143 See TAB SS 235 R1566/77 (dated 13 Apr 1877). 
this capacity at the official opening of the High Court. ${ }^{144}$ Soon after he seemingly fell ill and by the end of May had not yet officially handed over his previous office to his replacement. ${ }^{145} \mathrm{He}$ remained indisposed and could not resume his duties. ${ }^{146}$ The prognosis must not have been good, for in August his successor was appointed (see part 332 below). I found one letter from him, dated 25 February 1878, requesting an opportunity to consult his books, presumably those of his office. ${ }^{147}$ After his death, the Treasurer General requested instructions on how to direct claims against his office to Van Breda's estate. ${ }^{148}$

Van Breda left a widow, Sara Susanna, née Ziervogel. ${ }^{149}$ The estate took more than a year to finalise, and the widow must have suffered financially, because in February 1879 the executors requested that a gratuity be paid to her. ${ }^{150}$ The last correspondence regarding the estate dates from June 1879. ${ }^{151}$

\section{Henry Rider Haggard ${ }^{152}$}

Henry Rider Haggard, the well-known author of, among other works, King Solomon's Mines, was born in Bradenham, Norfolk, England on 22 June 1856. He was one of ten children; his father was an attorney and land reformer. Rider Haggard received his formal education at Ipswich Grammar School. Shortly after, in 1875, he arrived in Pietermaritzburg as a member of staff of Sir Henry Bulwer, ${ }^{153}$ the newly appointed

144 See n 22 supra. I could find only one document sent by Van Breda in his capacity as Registrar and Master, namely that of a request for supplies for the High Court: see TAB SS 237 R1932/77.

145 See TAB SS 237 R2037/77 (dated 30 May 1877).

146 See TAB SS 268 R634/78.

147 See TAB SS 267 R585/78.

148 See TAB SS 274 R1054/78 (dated 9 Apr 1878).

149 See TAB MHG 0/933. This explains Van Breda's request that CF Ziervogel, probably one of his in-laws, be considered as magistrate of Middelburg: see TAB SS 192 R1700/75 (dated 12 Aug 1875).

150 See TAB SS 328 R471/79 (dated 8 Feb 1879).

151 See TAB SS 348 R2126/79 (dated 11 Jun 1879) and TAB SS 348 R2131/79 (dated 23 Jun 1879).

152 See, in general, Goedhals 1968: 355-356.

153 Henry Ernest Gascoyne Bulwer (1836-1914) was born and died in Heydon Hall, Norfolk, England. He received his basic education at Charterhouse School and obtained a BA degree at Cambridge University in 1859 . He was appointed to various governmental positions on Prince Edward Island, the Ionian Islands, Trinidad, Dominica, the Leeward Islands, Labuan and Borneo, before being sent to Natal as Lieutenant General in 1875. He was known as a "level-headed ruler who preserved a calm outlook on political affairs". It was his task to establish peace in the troubled colony. He tried to prevent war, and during the eventual Anglo-Zulu War of 1879 he often disagreed with Lord Chelmsford (Lieutenant General Frederic Thesiger), the British military commander. Chelmsford's army would later suffer defeat by Cetshwayo's Zulu army at the famous Battle of iSandlwana on 22 Jan 1879. This battle served as inspiration for the well-known song "Impi", penned by song-writer activist, Johnny Clegg. Much has been written about the Anglo-Zulu War; for a recent account of the battles of iSandlwana and Rorke's Drift, see Knight 2010: passim. Bulwer was involved in the education system in Natal, and personally drafted Act 15 of 1877 , which concerned an improved primary education and established aboard 
Lieutenant General of Natal. In 1877, he accompanied Shepstone to the Transvaal as a member of his staff. It was Rider Haggard who, for the first time, hoisted the Union Jack on Church Square on 24 May 1877. ${ }^{154}$

Despite his lack of legal training, he succeeded Hendrik van Breda as Registrar and Master of the High Court on 3 August 1877. In a letter to his father, dated 7 April 1878 and written eight months after assuming this position, Rider Haggard wrote that-

I had not the slightest knowledge of my work, a good deal of which is of course technical, and what is more there were no records, no books, indeed nothing from which I could form an idea of it, nor had I anyone to teach me. ${ }^{155}$

Rider Haggard commented on the litigiousness of the Boers. He considered it outrageous to "spend hundreds or even thousands of pounds over the question of the ownership of a piece of land that was worth little". Moreover, he was not impressed that some lawyers overcharged their clients. He recalled one bill of costs in the amount of $£ 600$ that came before him for taxation. He taxed it down by half, but the unnamed lawyer didn't want to accept this and appealed to the High Court, where, after an entire day's worth of arguments, the court finally ordered Rider Haggard to "restore an amount of, I think, six and eightpence". ${ }^{156}$ Despite his lack of experience, Rider Haggard implemented at least one innovation during his term: he introduced a stamp system that involved stamps to be affixed to the bill of costs to ensure that the required percentage of the bill would be handed over to the Treasury. ${ }^{157}$

of education. Act 16 of 1877 provided for the establishment of high schools at Pietermaritzburg and Durban, and aimed for an improved public schooling for girls. However, he has been criticised for his top-down approach, and for failing to address other important education matters. He was also involved in the administration of justice, and played a particular role in the administration of "Bantu law" and in the establishment of a High Court for "Bantu matters". He left Natal in Apr 1880, but was recalled two years later, this time as Governor of Natal. His aim in that capacity was to enable self-government for the territory, but this was frustrated when responsible government was rejected at the polls in 1882. Despite this setback, he continued to work towards conferring self-government. He eventually left Natal in 1885, after which he was appointed as High Commissioner of Cyprus. He retired in 1892 and was knighted in 1864, 1874 and again in 1883. See, in general, Leverton 1972b: 101-103.

154 And not on 12 April 1877 as incorrectly reported in some sources. Kotzé 1934: 355 n 1 pointed out the error in Theal 1919 vol 1: 274. However, see Jorissen 1897:33, who remembered the Union Jack being hoisted on Church Square on 12 Apr 1877. Shepstone purposefully delayed the hoisting of the Union Jack upon annexation to prevent Boer hostilities; instead, the flag was only unfurled on Queen Victoria's 58th birthday more than a month later.

155 Rider Haggard 1926: 114.

156 Idem at 109 . However, bearing in mind that $£ 600$ was the annual salary of the Attorney General at the time, this amount is probably exaggerated: see n 109 supra. For more on the overcharging of the Transvaal lawyers, see Wildenboer 2011: 354-356.

157 Rider Haggard 1926: 109-110. 
As part of his duties, he also accompanied Kotzé on circuit during August $1877^{158}$ and August $1878 .{ }^{159}$ Kotzé fondly remembered the first circuit, which had hearings at Middelburg, Lydenburg, Wakkerstroom, Heidelberg, Potchefstroom and Rustenburg. Ford, the acting Attorney General at the time, and Juta, the High Sheriff, also accompanied Kotzé and Rider Haggard on this journey: Ford to conduct prosecutions, and Juta to select a deputy sheriff in each district. The members of the court traveled in two light wagons, each drawn by eight oxen because of a lack of horses or mules at the time. Juta had to see to the provisions and "proved himself to be an excellent commissariat". En route the wagons also served as sleeping quarters, while Kotzé and Rider Haggard ensured that the party was "well supplied with fresh meat" for the entire journey. Rider Haggard had come well prepared and brought with him for this purpose "a fowling piece and his horse, as well as his famous pointer Ben". However, it seems that Rider Haggard was not yet fully skilled at hunting as he "was a better marksman with his shot-gun than his rifle", a Martini Henry. ${ }^{160}$ It was on the occasion of Rider Haggard's shooting (and wounding) his first antelope, a blesbok, that he had an adventure of his own that surely was worth his recounting at future social evenings. ${ }^{161}$ After firing the shot, he became lost and had to sleep in the veld with his horse tied to his left arm and using his saddle as a pillow. His active imagination kept him from sleeping for most of the night and "he imagined that he heard all kinds of weird noises and cries", probably made by jackal, as drily pointed out by the Judge. Fortunately for Rider Haggard, it was a "calm and bright starlight night" and his servant eventually found him and lead him back to the wagons. ${ }^{162}$ Rider Haggard further made himself useful to his traveling

158 For a description of this circuit, see Kotzé 1934: 458-486. During this journey, Kotzé and Rider Haggard met an Australian, one Palmer, who had come to South Africa for some hunting. Kotzé invited him to travel with them from Middelburg to Wakkerstroom. The Judge was impressed with Palmer's wagon, an "American ox-wagon or "prairie schooner"" and described the comfort and conveniences of the wagon in some detail (at 521-522). The Judge was therefore pleased when the government bought the wagon from Palmer a few weeks later when he arrived in Pretoria to dispose of his belongings. The wagon was henceforth used for circuit court journeys.

159 See idem at 517-523. This second circuit court went to Middelburg, Lydenburg, Wakkerstroom and Heidelberg. In May 1879, the third circuit court went to Potchefstroom, Zeerust and Rustenburg. See idem at 626-635. By this time, Rider Haggard had resigned as Registrar and only traveled with the party as far as Six Mile Spruit, where he said his farewells on his journey to Natal. Accompanying Kotzé on this circuit was Henry Cloete (who would act as Crown Prosecutor), one Dawson (the Judge's secretary, who would also act as Registrar), Bishop Bousfield and the latter's fifteen-year old son, Hugh.

160 Idem at 458-459. Rider Haggard's skill with the rifle increased to such an extent that a year later, while on circuit, he was able to shoot two blesbok with one bullet: see idem at 519 .

161 See n 168 infra.

162 Kotzé 1934: 459-461. 
companions when he proved to be "an excellent cook" and "a first-class chef". ${ }^{163}$ It was during this circuit court that the members of the court also visited one of the Wonderfontein caves ${ }^{164}$ which so impressed him that he later used it as inspiration in King Solomon's Mines. ${ }^{165}$

During the First Anglo-Boer War, Rider Haggard joined the volunteers' corps to defend Pretoria. In May 1879 he resigned ${ }^{166}$ as Registrar and Master and returned to England, where he met and married Mariana Louisa Margitson. Four children were born of this marriage. They returned to Natal in December 1880 to take up ostrich farming, but when this venture failed, the couple returned to England after the First Anglo-Boer War.

There, and due to Kotzé's influence, ${ }^{167}$ Rider Haggard joined Lincoln's Inn and commenced his legal training. During this time, he also wrote for newspapers and published his first books. ${ }^{168} \mathrm{He}$ wrote King Solomon's Mines ${ }^{169}$ in a mere six weeks, and as part of a bet with his brother to compete with Robert Louis Stevenson's

163 See idem at 465. Rider Haggard cooked whatever meat was available on the day (such as venison, korhaan or red-wing partridge) in a baking pot, "steamed the potatoes to perfection" and sometimes "prepare[d] more dainty dishes, such as roast snipe on toast". Dawson, who acted as Registrar during a third circuit court in May 1879, was also expected to prepare the food. Kotzé recounted the incident where Dawson burnt the one side of his moustache. Fortunately nothing but Dawson's pride was hurt, as he "was very proud of his moustache". The rest of the group was not very sympathetic and instead took the opportunity to make fun of Dawson, telling him that he could not attend church the next morning with half a moustache. In the end, they persuaded him that there was nothing left but to shave off the other half of the moustache as well, and this was done by Bishop Bousfield himself, who happened to have a pair of scissors at hand: see idem at 634-635.

164 The Wonderfontein caves (or Wonder Cave) is situated at Kromdraai, Gauteng, and is the thirdlargest cave chamber in South Africa. It is still an attraction for spelunkers, and is listed by Triposo (an online, social travel site) as one of the seven amazing caves in the country: see Chloé $s d$. For an account of the Wonderfontein caves by a recent spelunker, see Van der Schyff 2014:passim.

165 Kotzé 1934:481-482. The group explored the caves by candle light and was amazed by the stalactites, and also by a structure resembling a pulpit, which, of course, would have been a stalagmite.

166 Rider Haggard sent two letters of resignation, namely on 4 and 29 May 1879: see TAB SS 341 R1547/79 and TAB SS 344 R1777/79 respectively. It is not clear why he felt the need to confirm his original intention, as word must have spread quickly after his first letter: three days after, nine candidates had already applied for his soon-to-be vacant post: see TAB SS 341 R1536/79 (dated 7 May 1879). See, also, n 173 infra.

167 Elsewhere, Kotzé 1934: 388-389 n 2 described Rider Haggard as "my old friend" and as "genial, high-spirited and romantic" (at 465). However, he bemoans the fact that Rider Haggard was prejudiced against the Boers and that he "could not be persuaded into visiting [their] homes" (at 523). He blamed his mindset on the general anti-Boer sentiment in Natal, where Rider Haggard had resided before coming to the Transvaal (at 524).

168 Kotzé 1934: 451 remembered that Rider Haggard had written his first short stories - published in English publications, such as the Gentleman's Magazine (a monthly magazine published between 1731 and 1922) or the Cornhill (a monthly magazine published between 1860 and 1975) - based on anecdotes of frontier life in the Cape, told by none other than Shepstone himself during social evenings at Government House.

169 For two recent reviews of King Solomon's Mines, see Foden 2007 and Rundell 2014: 33-34. 
popular Treasure Island. Various other novels followed, all written as adventure stories and many of them set in Africa. ${ }^{170}$ His passion for farming and social reform would later also feature in works, such as The Farmer's Year Book, Rural England and The Poor and the Land.

Rider Haggard also traveled extensively. He was knighted in 1912, and he became a Knight Commander of the British Empire in 1919. He died in London on 14 May 1924.

\section{Richard Kelsey Loveday ${ }^{171}$}

Loveday was born in Pietermaritzburg on 4 August 1854. He received his basic education in Natal, but started working at the tender age of fourteen. A few years later, he moved to the ZAR for health reasons, where he joined the civil service. ${ }^{172}$ He was one of at least nine candidates who applied for Rider Haggard's vacant post. ${ }^{173}$ Successful, he succeeded Rider Haggard as the Registrar and Master in an acting capacity. ${ }^{174}$ In October 1880 he was again appointed in this position in an acting capacity. ${ }^{175}$

After the First Anglo-Boer War, Loveday was not re-appointed, probably due to his participation in defending Pretoria against the Boers during the war. ${ }^{176}$ Nevertheless, he remained in Pretoria for the rest of his life and accepted the ZAR as his homeland. He then busied himself with various other duties, including land surveying, although he was not professionally trained as such. In 1885 he was appointed a Fellow of the Royal Geographical Society after compiling and publishing a map of the Lydenburg gold fields. ${ }^{177}$ Between 1891 and 1900 he was the

170 For an overview of his work, see Etherington 1984: passim.

171 See, in general, Cloete 1968: 500-501.

172 He already showed an interest in surveying at this early stage, as he applied to the Surveyor General's office for the position of draughtsman on 11 Dec 1878: see TAB SS 317 R4351/78. It is not clear whether his application was successful.

173 See TAB SS 341 R1536/79 (dated 7 May 1879). The other eight candidates were AS Dauson, F Jeppe, CHR Norman, J Vogel, W Atlely, F Coppen, FC Faure and H Browne. See, also n 166 supra.

174 The date of his appointment is not certain; I could not find any official documentation in this regard. Cloete 1968: 501 gives the date of his appointment as 1 Jun 1879, which is probably correct as Rider Haggard had already left Pretoria by the middle of May: see n 159 supra. By the end of that year, Loveday's provisional appointment had not yet been confirmed: see the letter by Loveday dated 29 Dec 1879 at TAB SS 378 R4501/79. I could not find any correspondence in response to this letter.

175 He was also instructed by the Administrator to take over the official records of the Attorney General on 4 Feb 1880, a week before Morcom took office as Maasdorp's successor in that role: see TAB SS 392 R509/80. This was probably only an interim measure until Morcom could commence his duties.

176 According to Kotzé 1934: 748, Loveday had the rank of captain and commanded the fourth company. See, also, Loveday's suggestions for a volunteer artillery corps: TAB SS 404 R1123/80 (dated 12 Mar 1880).

177 For more on the Lydenburg gold fields in general, see Glynn sd: 28-42. 
Volksraad representative for Barberton, and became known for his progressive and liberal views. ${ }^{178} \mathrm{He}$ was especially concerned with matters regarding administration and education. From 1897 to 1900 he was twice appointed by Kruger himself as member of the first and second interim Pretoria municipality. ${ }^{179}$ During the Second Anglo-Boer War, the British appointed him acting mayor of Pretoria, ${ }^{180}$ and after that war he was elected as a member of the city council, which he served until his death. ${ }^{181}$ In addition, during this time, he served in various other capacities, such as member of the legislative council of the Transvaal, the central judicial commission and the railway commission.

Loveday was furthermore interested in nature conservation and was one of those who, in 1898, proposed the motion in the Volksraad for proclaiming the Kruger National Park. ${ }^{182} \mathrm{He}$ was an avid rugby player and cricketer, ${ }^{183}$ and displayed some skill as a hunter. ${ }^{184}$

He was married to Augusta Magdalena Wilhelmina Juta, the daughter of JC Juta, ${ }^{185}$ and of the marriage was born four daughters and two sons. He died in Pretoria on 10 July 1910.

\section{Conclusion}

The establishment of the High Court of Transvaal was long overdue. By 1877, the Transvaal was the only territory in what would later become South Africa that did not have a high court. What's more, at the time, the Transvaal did not have the necessary resources at its disposal for the establishment of such a court. Not only was the country on the verge of bankruptcy, but it had very few qualified lawyers to serve as judicial officers. President Burgers had to appoint an outsider, and a young lawyer at that, to the bench of the envisioned new court. The Attorney General at the time was not a qualified lawyer either, and his predecessor, who had the necessary

178 Fitzpatrick 1899: 64 describes him as being the only progressive element in the Volksraad in 1888, although his views influenced others.

179 See, also, Gey van Pittius 1955: 50. The first interim municipality consisted of fifteen members, which included a district surgeon (Dr G Messum), a city engineer (E Lutz) and the magistrate (CE Schutte).

180 See, also, idem at 58.

181 See, however, the cartoon reprinted at Pelzer 1955: 326, where Loveday is depicted as one of the fence sitters regarding the issue of responsible or representative government.

182 See Joubert 2007: 1-22 for a general overview of the history of the Park; Loveday and JL van Wyk are specifically mentioned for their efforts in persuading the ZAR government to eventually proclaim the Gouvernement Wildtuin on 26 Mar 1898 (idem at 1-2).

183 Vlok 1955: 235.

184 He often accompanied none other than Kotzé on hunting trips to the Pretoria surroundings, where they hunted mostly fowl and antelope. Kotzé 1934: 452 described Loveday as a "first-rate shot".

185 See n 23 supra. 
training and legal skills, had left the Transvaal in search of greener pastures. The capital, Pretoria, did not even have a dedicated court building.

Nevertheless, during the first four years of its existence, slow but steady changes were implemented. In order to encourage a fully qualified bench and Bar, several interventions were made: formal requirements were set for the admission of advocates and attorneys; a new examining body was established; and a divided legal profession was implemented. In addition, the judicial officers were required to have the necessary qualifications. However, sometimes appointments still had to be made as a matter of urgency when the administrative needs of the court became more pressing than having to wait for a suitable candidate to be found abroad.

During these four years, the Transvaal found itself in political turmoil, eventually culminating in the First Anglo-Boer War. One is therefore perhaps a bit surprised that the day-to-day activities of the court continued as usual; that apart from political differences and views, personal prejudices also still played a role, not only in the appointment of law officers, but also within the court itself. Yet, despite the threat of war in the Transvaal, and the reality of war in Natal, in court it was mostly business as usual. The court had to decide on various civil matters, such as divorces, deceased estates and boundary disputes, and had to hear the usual criminal cases. Individuals still had to earn a living. Life, therefore, continued steadily as always, at least within the court room. It is tempting to think that the rules and formalities of the court served as a reprieve from the political tension for those who earned their living there. But perhaps that is the entire point of the legal system: to provide order for societies in strife.

\section{Bibliography}

Anonymous (1900) "Notes: The Hon J G Kotze [sic]" Cape LJ 17: 207

Anonymous (1903) “The Hon J G Kotze [sic]” SALJ 20: 101-110

Anonymous (1940) “The late Sir John Kotzé” SALJ 57: 159-160

Anonymous (1968) sv "Du Toit, Stephanus Jacobus" in Suid-Afrikaanse Biografiese Woordeboek vol 1 (Cape Town): 279-283

Arkin, M (1972) sv “Juta, Jan Carel” in Dictionary of South African Biography vol 2 (Cape Town): 352 353

Behrens, HPH (1955) “The Pretoria Press Story” in SP Engelbrecht et al (eds) Pretoria (18551955): History of the City of Pretoria (Pretoria): 332-360

Bergh, JS (2013) “A perspective on State President SJP Kruger: Chief Justice JG Kotzé’s Biographical Memoirs and Reminiscences” Historia 58(1): 106-121

British Parliamentary Papers (1971) Irish University Press Series Colonies Africa vol 36: Transvaal (Shannon)

Chloé, Irena (sd) "7 Amazing caves in South Africa" available at https://www.triposo.com/ layer/lyepyoe (accessed 8 Nov 2019) 
Cloete, JJN (1968) sv "Loveday, Richard Kelsey" in Suid-Afrikaanse Biografiese Woordeboek vol 1 (Cape Town): 500-501

Engelbrecht, SP (1955) "Pretoria - Die eerste halfeeu" in SP Engelbrecht et al (eds) Pretoria (18551955): History of the City of Pretoria (Pretoria): 1-30

Etherington, Norman (1984) Rider Haggard (Boston)

Eybers, GW (1918) Select Constitutional Documents Illustrating South African History 17951910 (London)

Fitzpatrick, JP (1899) The Transvaal from Within: A Private Record of Public Affairs (London)

Foden, Giles (2007) "Boy's own adventure" available at https://www.theguardian.com/ books/2007/nov/17/featuresreviews. guardianreview36 (accessed 12 Nov 2019)

Gey van Pittius, EFW (1955) "Munisipale bestuur in Pretoria: "n Geskiedkundige oorsig” in SP Engelbrecht et al (eds) Pretoria (1855-1955): History of the City of Pretoria (Pretoria): 4360

Glynn, Henry T (sd) Game and Gold: Memories of over 50 Years in the Lydenburg District, Transvaal (London)

Goedhals, JB (1968) sv "Haggard, sir Henry Rider" in Suid-Afrikaanse Biografiese Woordeboek vol 1 (Cape Town): 355-356

Gordon, RE \& DA Kotzé (1968) sv "Shepstone, Theophilus" in Suid-Afrikaanse Biografiese Woordeboek vol 1 (Cape Town): 746-753

Grobler, Jackie (2018) Die Eerste Vryheidsoorlog 1880-1881 (Centurion)

Hahlo, HR \& Ellison Kahn (1960) South Africa: The Development of its Laws and Constitution (London)

Hiemstra, VG (1968) sv "Kotzé, Johannes Gysbert (Sir John Gilbert)" in Suid-Afrikaanse Biografiese Woordeboek vol 1 (Cape Town): 458-461

Holm, Dieter (1998) "Kerksplaats and capitalists: The first architects in context" in Roger C Fisher, Schalk le Roux \& Estelle Maré (eds) Architecture of the Transvaal (Pretoria): 55-77

Ilbert, CP (1916) "Review: The Grotius Society” Journal of the Society of Comparative Legislation 16(2): 381-383

Jeppe, Fred \& JG Kotzé (1887) De Locale Wetten der Zuid Afrikaansche Republiek, 1849-1885 (Pretoria)

Jorissen, EJP (1897) Transvaalsche Herinneringen 1876-1896 (Amsterdam)

Joubert, Salomon (2007) The Kruger National Park: A History vol 1 (Johannesburg)

Kew, James Winston (1979) John Gilbert Kotzé and the Chief Justiceship of the Transvaal, 18771881 (MA thesis, University of South Africa)

Knight, Ian (2010) Zulu Rising: The Epic Story of iSandlwana and Rorke's Drift (London)

Kotzé, J (1934) Biographical Memoirs and Reminiscences vol 1 (Cape Town)

Kotzé, JG (1949) Memoirs and Reminiscences vol 2 (Cape Town)

Kotzé, JG (1885) Cases Decided in the High Court of the Transvaal Province, with Table of Cases and Alphabetical Index (Pretoria)

Kruger, Louis Stephanus (1975) Die Rol van Dr EJP Jorissen in die Geskiedenis van die ZuidAfrikaansche Republiek (D Phil, University of the Orange Free State) 
Leverton, BJT (1972a) sv "Bale, Sir Henry" in Dictionary of South African Biography vol 2 (Cape Town): 23-24

Leverton, BJT (1972b) sv "Bulwer, Henry Ernest Gascoyne" in Dictionary of South African Biography vol 2 (Cape Town): 101-103

Leverton, BJT (1972c) sv "Morcom, William Boase" in Dictionary of South African Biography vol 2 (Cape Town): 494

Leverton, BJT (1977) sv "Gallwey, Sir Michael Henry" in Suid-Afrikaanse Biografiese Woordeboek vol 3 (Cape Town): 323-324

Meiring, AL (1955) "Stadsbeplanning en boukuns in Pretoria: 'n Terugblik" in SP Engelbrecht et al (eds) Pretoria (1855-1955): History of the City of Pretoria (Pretoria): 148-172

Moll, JC (1972) sv "Buchanan, James" in Dictionary of South African Biography vol 2 (Cape Town): 95-96

Nathan, Manfred (1932a) “The Republican Bench and Bar” South African Law Times 1(1): 13-14

Nathan, Manfred (1932b) “The Republican Bench and Bar Part II” South African Law Times 1(2): $39-41$

Nienaber, PJ (1972) sv “Celliers, Johannes François” in Dictionary of South African Biography vol 2 (Cape Town): 128-129

Pelzer, AN (1955) "Pretoria in die karikatuur" in SP Engelbrecht et al (eds) Pretoria (1855-1955): History of the City of Pretoria (Pretoria): 295-331

Picton-Seymour, Désirée (1977) Victorian Buildings in South Africa (Cape Town)

Ploeger, J (1972) sv "Jorissen, Eduard Johan Pieter" in Dictionary of South African Biography vol 2 (Cape Town): 344-347

Ploeger, J (1977a) sv "Jorissen, Samuel Gerhard" in Suid-Afrikaanse Biografiese Woordeboek vol 3 (Cape Town): 467-468

Ploeger, J (1977b) sv "Van Gorkom, Wilhelm Johan" in Suid-Afrikaanse Biografiese Woordeboek vol 3 (Cape Town): 825-826

Rider Haggard, H (1926) The Days of my Life: An Autobiography by Sir H Rider Haggard ed by CJ Longman (London)

Roberts, AA (1942) A South African Legal Bibliography (Pretoria)

Roberts, Adrian A (1955) "The Bar in Pretoria" in SP Engelbrecht et al (eds) Pretoria (18551955): History of the City of Pretoria (Pretoria): 173-194

Rundel, Katherine (2014) "Fashionable gore" London Review of Books 36(7): 33-34 available at https://www.lrb.co.uk/v36/n07/katherine-rundell/fashionable-gore (accessed 12 Nov 2019)

Schulze, WG (2010) ““One JP de Wet'. South Africa’s first judicial export?” Fundamina 16(2): 98-120

Scott, J (1982) "The administration of justice in the Transvaal 1836-1910" in Association of the Law Societies of the Republic of South Africa Our Legal Heritage (Durban): 91-104

Smith, AH \& A Cunningham (1987) sv "Ford, Lewis Peter" in Dictionary of South African Biography vol 5 (Pretoria): 272-273

Spoelstra, B (1968) sv “Swart, Nicolaas Jacob Reinier" in Suid-Afrikaanse Biografiese Woordeboek vol 1 (Cape Town): 817-818 
Theal, George McCall (1919) History of South Africa from 1873 to 18842 vols (London)

Van der Merwe, D (2017a) "Brown v Leyds NO (1897) 4 OR 17: A constitutional drama in four acts. Act one: The 1858 Constitution of the Zuid-Afrikaansche Republiek" Fundamina 23(1): 111-165

Van der Merwe, D (2017b) “Brown v Leyds NO (1897) 4 OR 17: A constitutional drama in four acts. Act two: The 1858 ZAR Constitution, malleable instrument of Transvaal realpolitik (1859-1881)" Fundamina 23(2): 118-175

Van der Merwe, D (2018a) "Brown v Leyds NO (1897) 4 OR 17: A constitutional drama in four acts. Act three: The king's voice speaks through the 1858 ZAR Constitution to President and Chief Justice (1884-1895)" Fundamina 24(1): 89-133

Van der Merwe, D (2018b) “Brown v Leyds NO (1897) 4 OR 17: A constitutional drama in four acts. Act four: Kotzé delivers his judgement, Kruger dismisses him, Milner prepares for war and Brown seeks international redress" Fundamina 24(2): 120-160

Van der Schyff, Veronica (2014) “The wonder of Wonderfontein” Speleological Exploration Club available at http://www.sec-caving.co.za/2014/04/the-wonder-of-wonderfontein.html (accessed 8 Nov 2019)

Van der Westhuizen, JV \& D van der Merwe (1977a) "Die geskiedenis van die regspleging in Transvaal (1852-1877)" De Jure 10: 92-108

Van der Westhuizen, JV \& D van der Merwe (1977b) "Die geskiedenis van die regspleging in Transvaal (1877-1910)" De Jure 10: 237-260

Van Niekerk, JP (2013) “An introduction to South African law reports and reporters, 1828 to 1910" Fundamina 19(1): 106-145

Van Tonder, SIE (1968) sv "sir Andries Ferdinand(us) Stockenström" in Suid-Afrikaanse Biografiese Woordeboek vol 1 (Cape Town): 504-505

Van Warmelo, P (1987) sv "Maasdorp, Christian George" in Dictionary of South African Biography vol 5 (Pretoria): 479-480

Vlok, JC (1955) “A century of sport” in SP Engelbrecht et al (eds) Pretoria (1855-1955): History of the City of Pretoria (Pretoria): 231-243

Wildenboer, L (2010) "The origins of the division of the legal profession in South Africa: A brief overview” Fundamina 16(2): 199-225

Wildenboer, L (2011) "For a few dollars more: Overcharging and misconduct in the legal profession of the Zuid-Afrikaansche Republiek" De Jure 44: 339-363

Wildenboer, L (2015) "The Thirty-Three Articles and the application of law in the ZuidAfrikaansche Republiek" Fundamina 21(2): 457-476

\section{Case law}

Brown v Leyds NO (1897) 4 Off Rep 17

EJP Jorissen $v$ The State (1896) 3 Off Rep 153

Trustees in the Insolvent Estate of Theodore Doms v Bok No (1887) 2 SAR 18 